\title{
Activation of Both CB1 and CB2 Endocannabinoid Receptors Is Critical for Masculinization of the Developing Medial Amygdala and Juvenile Social Play Behavior
}

\author{
(1)Kathryn J Argue, Jonathan W VanRyzin, David J Falvo, Allison R Whitaker, (DStacey J Yu, and \\ (1) Margaret M McCarthy
}

DOI:http://dx.doi.org/10.1523/ENEURO.0344-16.2017

Department of Pharmacology, University of Maryland School of Medicine, Baltimore, MD 21201

\begin{abstract}
Juvenile social play behavior is a shared trait across a wide variety of mammalian species. When play is characterized by the frequency or duration of physical contact, males usually display more play relative to females. The endocannabinoid system contributes to the development of the sex difference in social play behavior in rats. Treating newborn pups with a nonspecific endocannabinoid agonist, WIN55,212-2, masculinizes subsequent juvenile rough-and-tumble play behavior by females. Here we use specific drugs to target signaling through either the CB1 or CB2 endocannabinoid receptor (CB1R or CB2R) to determine which modulates the development of sex differences in play. Our data reveal that signaling through both $\mathrm{CB} 1 \mathrm{R}$ and $\mathrm{CB} 2 \mathrm{R}$ must be altered neonatally to modify development of neural circuitry regulating sex differences in play. Neonatal co-agonism of CB1R and CB2R masculinized play by females, whereas co-antagonism of these receptors feminized rates of male play. Because of a known role for the medial amygdala in the sexual differentiation of play, we reconstructed Golgi-impregnated neurons in the juvenile medial amygdala and used factor analysis to identify morphological parameters that were sexually differentiated and responsive to dual agonism of CB1R and CB2R during the early postnatal period. Our results suggest that sex differences in the medial amygdala are modulated by the endocannabinoid system during early development. Sex differences in play behavior are loosely correlated with differences in neuronal morphology.
\end{abstract}

Key words: amygdala; development; endocannabinoid; juvenile play behavior; neuronal morphology; rat

\section{Significance Statement}

Juvenile social play behavior is a critical component for proper brain development and the acquisition of social competence in the majority of mammalian species. In juvenile rats, males exhibit higher numbers of rough-and-tumble play events relative to females. This difference in rat play behavior is programmed by the actions of steroid hormones during the early postnatal sensitive period for sexual differentiation of the brain. Here we demonstrate a requirement for combined activation or inhibition of both endocannabinoid receptors for masculinization or feminization of the neural circuitry for play, respectively. Furthermore, our findings suggest a correlation between playfulness and neuronal morphology in the medial amygdala.

Received November 17, 2016; accepted January 5, 2017; First published January 16, 2017.

Authors report no conflict of interest.
Author Contributions: $\mathrm{KJA}$ and $\mathrm{MMM}$ designed research and wrote the paper; KJA and JWVR analyzed data; KJA, DJF, ARW, and SJY performed research. 


\section{Introduction}

Conspecific social play is a critical component of the juvenile period for a wide variety of mammalian species (Gruendel and Arnold, 1969; Byers and Walker, 1995; Arthur et al., 1999; van den Berg et al., 1999; Spinka et al., 2001; Graham and Burghardt, 2010; Pellis et al., 2010; Siviy, 2016). Deficits in social play, including delayed onset, decreased intensity, problems responding to social cues, and withdrawal from social play situations leading to isolation, are observed in children diagnosed with psychiatric disorders, such as autism spectrum disorder, early-onset schizophrenia, and attention deficit hyperactivity disorder (Gruendel and Arnold, 1969; Byers and Walker, 1995; Arthur et al., 1999; van den Berg et al., 1999; Møller and Husby, 2000; Spinka et al., 2001; Jordan, 2003; Strous et al., 2004; Cordier et al., 2010; Graham and Burghardt, 2010; Pellis et al., 2010). Identifying variables contributing to individual playfulness and that produce a more desirable play partner will help elucidate factors critical for normal social development as well as how those factors are altered during aberrant development.

A common and trans-species form of social behavior is rough-and-tumble play, or play fighting (Henry and Herrero, 1974; Pellis and Pellis, 1997, 1998; Cordoni, 2009). In juvenile rats, rough-and-tumble play consists of a complex set of behaviors that require appropriate initiation and responses to play solicitation (Pellis et al., 1997; Himmler et al., 2014; Argue and McCarthy, 2015a). By postnatal day 20 (PN20), juvenile rats display the full repertoire of rough-and-tumble play behaviors, including initiation of play (pouncing) and responses to play solicitation (pinning; Pellis et al., 1997; Himmler et al., 2014; Argue and McCarthy, 2015a). The majority of species exhibit a sex difference in rough-and-tumble play, with males having increased frequency and duration relative to females (Leresche, 1976; Olioff and Stewart, 1978; Takahashi and Lore, 1983; Thor and Holloway, 1985, 1986; Watson and Croft, 1993; Pellis, 2002; Palagi et al., 2007; Parent and Meaney, 2008; Auger and Olesen, 2009; Krebs-Kraft et al., 2010; Argue and McCarthy, 2015a). However, there are some discrepancies in the literature regarding sex differences in rough-and-tumble play. When observations are made outside of a controlled environment, it is often difficult to determine how specific conditions of the study could have contributed to the findings. For example, in very young Gelada baboons, the sex with the greatest number of play bouts, defined by instances of play biting, mouthing, slapping, jumping at, tail pulling, object play, boxing, chasing, wrestling, and

This work was funded by R01MH052716-020 and R01DA039062-01 to MMM.

Correspondence should be addressed to Kathryn J Argue, Department of Pharmacology, University of Maryland, Baltimore, 655 W Baltimore St., Baltimore, MD 21201. E-mail: kargue@som.umaryland.edu.

DOI:http://dx.doi.org/10.1523/ENEURO.0344-16.2017

Copyright (C) 2017 Argue et al.

This is an open-access article distributed under the terms of the Creative Commons Attribution 4.0 International, which permits unrestricted use, distribution and reproduction in any medium provided that the original work is properly attributed. other nonspecified forms of rough-and-tumble play, varies depending on the month studied, with females playing more than males in the majority of months. However when animals of an older age cohort are observed, males consistently play more frequently (Barrett et al., 1992). In baboons, there are seasonal changes in levels of play in younger animals, with females playing more than males in the majority of months, and in older animals no sex difference is observed (Cheney 1978). This is just one example of many illustrating how different definitions of what constitutes social play, the age of the animals studied, and the specific conditions under which the animals are studied can impact the observation of sex differences in play. Sex differences in juvenile rough-and-tumble play of the popular laboratory species, Rattus norvegicus, have been found in the frequency of pouncing (play initiation), the frequency of pinning (playful defense), and the amount of time engaged in play. These observations can differ depending on the rat strain and methodology (i.e., whether play was assessed in a group or pairs and whether they consisted of same- or mixed-sex individuals; Argue and McCarthy, 2015b).

Execution of play behavior involves multiple brain regions. Meaney and McEwen (1986) determined that testosterone acting in the neonatal medial amygdala is sufficient to masculinize juvenile play behavior. In this same brain region, there is a developmental sex difference in the endocannabinoid system (Krebs-Kraft et al., 2010) which comprises two principal ligands, 2-arachidonoyl glycerol (2-AG) and anandamide (AEA), and two key receptors, CB1R and CB2R (Lu and Mackie, 2015). The developing male amygdala has higher levels of 2-AG and to a lesser extent, AEA, and pharmacologically increasing the endocannabinoid signal in neonatal females via administration of the nonspecific endocannabinoid agonist, WIN55,212-2, increases juvenile rough-andtumble play behavior to the levels observed in males (Krebs-Kraft et al., 2010). To further explore which endocannabinoid receptors transduce the endocannabinoid signal to modify development of the social play circuitry, we here use specific CB1R and CB2R agonists or antagonists and explore the impact of single or combined treatment.

\section{Materials and Methods}

\section{Animals}

Sprague-Dawley rats (Harlan) mated in our facility or ordered as pregnant dams were allowed to deliver normally under standard laboratory conditions (total $n=160$ pups from 16 litters). On the day of birth (PNO) pups were given paw tattoos to identify treatment groups. Pups were weaned on PN22 and housed in pairs or groups consisting of no more than three individuals of the same sex in polycarbonate cages $(20 \times 40 \times 20 \mathrm{~cm})$ with corncob bedding under a reverse 12:12 $\mathrm{h}$ light/dark cycle. Food and water were available ad libitum. All breeding and experimental procedures were approved by the Institutional Care and Use Committee at the University of Maryland, Baltimore and performed in accordance with national animal care and use guidelines. 


\section{Play experiment 1: effect of CB1R or CB2R specific agonists or antagonists on play behavior}

Pups were given daily intraperitoneal (i.p.) injections for four consecutive days (PNO-3). Females received 1 $\mathrm{mg} / \mathrm{kg}$ ACEA (a CB1-specific agonist; Tocris), $1 \mathrm{mg} / \mathrm{kg}$ GP1a (a CB2-specific agonist; Tocris), or vehicle (saline with $2 \%$ ethanol). Males received $1 \mathrm{mg} / \mathrm{kg} \mathrm{AM} 281$ (a CB1-specific antagonist/inverse agonist; Tocris), $1 \mathrm{mg} / \mathrm{kg}$ AM630 (a CB2-specific antagonist/inverse agonist; Tocris), or vehicle (saline with $2 \%$ ethanol and $2 \%$ DMSO; $n=$ 6-9 individuals from each treatment group). The injection site was sealed with VetBond (3M) to prevent leakage. On PN27, animals were tested for $10 \mathrm{~min}$ in a $96 \times 80 \times$ $41-\mathrm{cm}$ open field with a $16-\mathrm{cm}^{2}$ grid to rule out potential confounds that differences in activity or anxiety-like behavior might have on play. Behavior was videorecorded and scored to determine levels of locomotion (indicated by the number of gridlines crossed) or anxiety-like behavior (time spent in the center zone). On PN28-37, juvenile social play was assessed in groups of six consisting of noncagemates from each of the different treatment groups (female vehicle, male vehicle, female ACEA, female GP1a, male AM281, and male AM630). Animals were marked with a marker for identification and placed in a 49 $\times 37 \times 24-\mathrm{cm}$ enclosure with TEK-Fresh cellulose bedding (Harland Laboratories), allowed to acclimate for 2 $\mathrm{min}$, and videorecorded for $10 \mathrm{~min}$. All social play behavior occurred under red-light illumination during the dark phase of the cycle. The videos were scored to determine the number of times pouncing, pinning, or boxing behaviors occurred.

\section{Play experiment 2: effects of $\mathrm{CB} 1$ and $\mathrm{CB} 2$ receptor co-agonism on play behavior}

Pups were given daily i.p. injections (PNO-3) as described in Experiment 1. Male and female pups received 1 $\mathrm{mg} / \mathrm{kg}$ ACEA + $1 \mathrm{mg} / \mathrm{kg}$ GP1a, $1 \mathrm{mg} / \mathrm{kg}$ WIN55,212-2 (Tocris), or vehicle (saline with $4 \%$ ethanol; $n=6-9$ individuals from each treatment group). On PN27, animals were tested in the open field, and for 8 days (PN28-37), social play was assessed as described for Experiment 1. Animals were placed in groups of six consisting of noncagemates from each of the treatment groups (female vehicle, male vehicle, female ACEA+GP1a, female WIN, male ACEA+GP1a, male WIN).

\section{Play experiment 3: effects of CB1 and CB2 receptor co-antagonism on play behavior}

Pups were given daily i.p. injections (PNO-3) as described for Experiment 1. Male and female pups received $1 \mathrm{mg} / \mathrm{kg}$ AM281 $+1 \mathrm{mg} / \mathrm{kg} \mathrm{AM630}$ or vehicle (saline with $4 \%$ DMSO; $n=7-10$ individuals from each treatment group). On PN26, animals were tested in the open field, and on PN27-34, social play behavior was assessed as described for Experiment 1. For this experiment, animals were placed in same-sex/treatment pairs with a noncagemate partner rather than in a mixed-treatment/sex group. Pairing animals of the same sex and treatment and hence similar levels of playfulness helps to eliminate any effects that the play partners can have on an individual's play, such as a more playful partner increasing play in a con- tagious manner or a less playful partner reducing play through negative reinforcement. These effects of play partners are exemplified by the observations that malemale dyads will play more than mixed-sex pairs, whereas female-female dyads will play less than both male-male and mixed-sex pairs. This paired paradigm also increases the total number of play events observed for an individual relative to what is observed with a group paradigm.

\section{D neuronal reconstruction}

To reconstruct neurons on PN4, pups were anesthetized with FatalPlus and perfused intracardially with $0.9 \%$ saline ( $n=10$ animals of each sex). Brains were removed and placed into Golgi solution (1:1 solution of $5 \%$ potassium dichromate and 5\% mercuric chloride that was added to $5 \%$ potassium chromate in a 2:5 ratio) and left for $48 \mathrm{~h}$, after which the brains were switched to fresh Golgi solution where they remained for $8 \mathrm{~d}$. Brains were removed from Golgi solution and incubated in 30\% sucrose for $4 \mathrm{~d}$, followed by incubation in Solution $\mathrm{C}$ (from Cedarlane Labs FD Ropid GolgiStain Kit) for $4 \mathrm{~d}$. Brains were coronally sectioned on a cryostat at a thickness of $100 \mu \mathrm{m}$ and mounted onto gelatin-subbed slides. Slides were developed with incubation in a $30 \%$ ammonium hydroxide solution, then 1\% Dektol (Kodak) solution, and finally 18\% Fix (Kodak) solution, counterstained with $0.2 \%$ methylene blue, cleared with ascending alcohol, defatted with xylenes, and coverslipped with DPX mounting medium. Six neurons from $\geq 3$ different sections were reconstructed from the right and left hemisphere of each individual. Slides were numerically coded, blinding the tracer to the sex of each individual. Well-impregnated neurons were selected based on the presence of a filled cell body and dendrites that were filled to their ends. Because some cracking of the tissue did occur with the development protocol, only neurons that came to a natural end before reaching a crack were analyzed. These well-impregnated neurons were reconstructed under a $100 \times$ oil-immersion objective using Neurolucida (Microbrightfield) interfaced with a Nikon Eclipse E600 microscope and an MBF Bioscience CX9000 Digital Camera. Cell body area, number of primary dendrites, number of nodes (branch points on a dendritic process), spine density (total number of spines on each neuron divided by total dendritic length), total dendritic length, and average dendritic length (total dendritic length divided by number of primary dendrites) were quantified and compared (Fig. 1).

For the reconstruction of neurons on PN26, brains were taken as described above from behaviorally naive animals that were treated (PNO-3) with $1 \mathrm{mg} / \mathrm{kg}$ ACEA, $1 \mathrm{mg} / \mathrm{kg}$ GP1a or both, or vehicle (saline with $4 \%$ ethanol), via i.p. injection ( $n=3-4$ animals from each treatment group). Brains were impregnated, cut, stained, and reconstructed as described above except that they were incubated in Golgi solution for $12 \mathrm{~d}$ after the switch to fresh solution at $48 \mathrm{~h}$ postmortem. As done at PN4, six neurons from each hemisphere from each individual were reconstructed. 


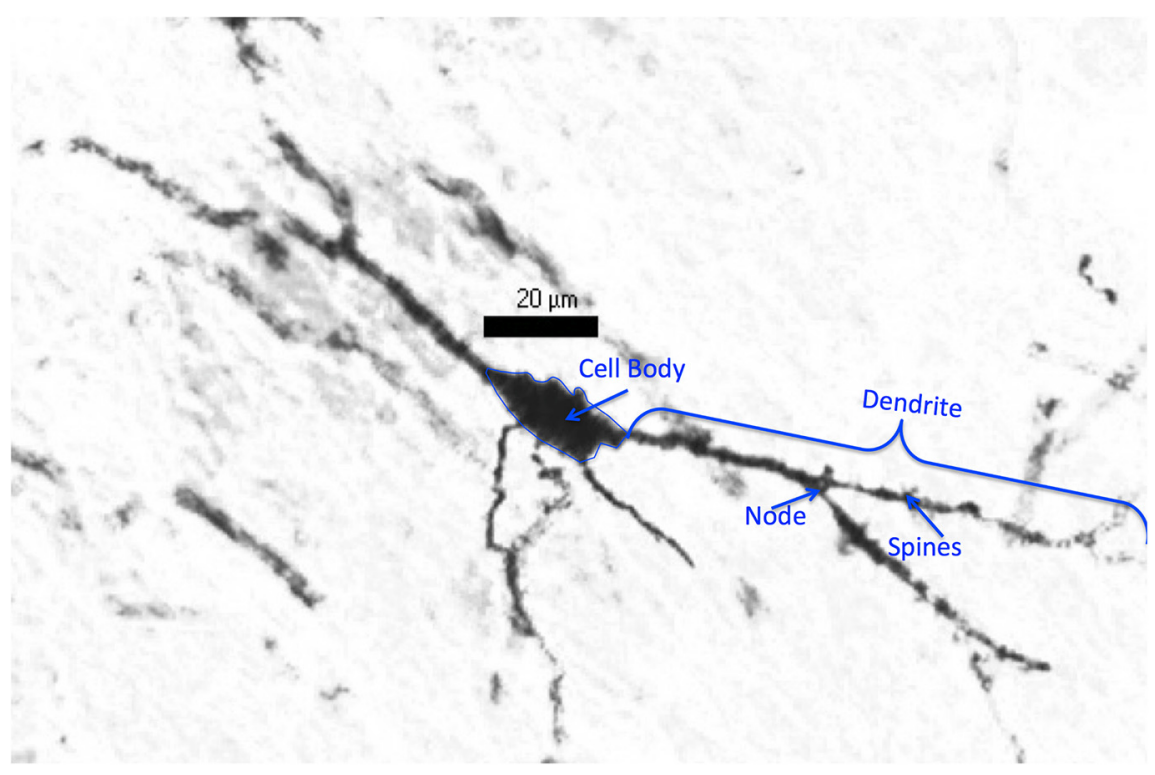

Fig. 1. Representative image of a PN26 Golgi-impregnated neuron. A Golgi-impregnated neuron was imaged at $40 \times$ magnification. The cell body is outlined, and a dendrite, node, and spine are indicated to illustrate the parameters of neuronal morphology that were included in our analysis.

\section{Statistical analysis}

Data analysis was performed using SPSS for Windows (IBM), GraphPad Prism, and R (version 3.2.1). All data sets were tested for normal distribution using a KolmogorovSmirnov test.

The total number of play events (total number of pounces, pins, and boxing events) was combined from all days of analysis. Outliers were removed using the ROUT method with $Q=1 \%$, and data were analyzed using either ANOVA or two-way ANOVA, as indicated for each experiment. Play was also split into its two major components, initiation of play (indicated by the number of pounces) and response to play initiation (indicated by the number of pins). Because of the infrequency of boxing events, this parameter was not analyzed independently. Pouncing and pinning were analyzed using either ANOVA or a two-way ANOVA, as indicated for each experiment. If a significant ANOVA or two-way ANOVA was obtained for frequency of play, pouncing, or pinning, $t$-tests with a Welch correction were performed to test a priori hypotheses. Open-field behavior (gridlines crossed and centering time) was analyzed by ANOVA or two-way ANOVA as indicated for each experiment.

Neuronal morphology at PN4 was analyzed by $t$-tests with a Welch correction. Parameters of neuronal morphology at PN26 were analyzed using factor analyses. The data were log transformed, and the factor analyses were performed with varimax rotation, which produces orthogonal values and preserves the variance of the original data. The resulting factors were retained if their eigenvalue was $>1$ (based on the Kaiser criterion), and a 0.3 significance cutoff was used to determine loading of a parameter into a factor. Individual factor scores were calculated for each cell and averaged with others from the same experimental groups. These data were analyzed using ANOVA or $t$-tests with a Welch correction.
For all analyses, differences were considered significant when $p<0.05$. All data are depicted as mean with SEM. The results for all analyses are shown in Table 1. Superscript letters listed with $p$-values correspond to the statistical tests shown in Table 1.

\section{Results}

\section{Effects of select CB1R or CB2R agonism or antagonism during early development on juvenile rough-and-tumble play behavior}

To determine whether the increase in female juvenile rough-and-tumble play behavior that was observed after neonatal treatment with WIN55,212-2 was due to signaling through the CB1R or CB2R, female pups (PNO-3) were treated daily with ACEA (a CB1R-specific agonist) or GP1a (a CB2R-specific agonist). The total number of play events in ACEA- and GP1a-treated females was comparable to that of vehicle-treated females ${ }^{a}$ (Fig. 2A, B). A breakdown of play into initiation (number of pounces) or response (number of pins) also demonstrated no effects of treatment ${ }^{\mathrm{b}, \mathrm{c}}$ (Figs. $3 A, B$ and $4 A, B$ ). Open-field behavior was assessed to determine whether there were changes in locomotor (gridlines crossed) or anxiety-like (time spent in the center zone) behavior that could impact social play behavior. There was no effect of treatment with ACEA or GP1a on the number of gridlines crossed ${ }^{d}$ or time spent in the center zone ${ }^{e}$ (data not shown).

Neonatal treatment with the pan-CBR agonist WIN55, 212-2 does not effect play in juvenile males (Krebs-Kraft et al., 2010). Therefore we sought to determine whether antagonism of the CB1R and CB2R would decrease male play behavior. Neonatal male pups (PNO-3) were treated daily with AM251 (a CB1R-specific antagonist/inverse agonist) or AM630 (a CB2R-specific antagonist/inverse agonist). Treatment with AM281 or AM630 did not alter the 
Table 1. Summary of statistical analysis.

\begin{tabular}{|c|c|c|c|c|c|}
\hline Line & Data analyzed & Results & Data structure & Type of test & $\begin{array}{l}\text { Observed power or } \\
\text { confidence interval }\end{array}$ \\
\hline a & Total play: female vehicle, female ACEA, female GP1a & $F(2,224)=0.28, p=0.756$ & Normal & ANOVA & 0.094 \\
\hline $\mathrm{b}$ & Pouncing: female vehicle, female ACEA, female GP1a & $F(2,222)=0.2 .713, p=0.069$ & Normal & ANOVA & 0.533 \\
\hline $\mathrm{c}$ & Pinning: female vehicle, female ACEA, female GP1a & $F(2,210)=0.699, p=0.498$ & Normal & ANOVA & 0.167 \\
\hline d & Number of gridlines crossed: female vehicle, female ACEA, female GP1a & $F(2,23)=1.008, p=0.383$ & Normal & ANOVA & 0.201 \\
\hline e & Time spent in the center zone: female vehicle, female ACEA, female GP1a & $F(2,23)=0.262, p=0.772$ & Normal & ANOVA & 0.086 \\
\hline$f$ & Total play: male vehicle, male AM281, male AM630 & $F(2,208)=1.314, p=0.271$ & Normal & ANOVA & 0.282 \\
\hline $\mathrm{g}$ & Pouncing: male vehicle, male AM281, male AM630 & $F(2,208)=2.103, p=0.125$ & Normal & ANOVA & 0.429 \\
\hline $\mathrm{h}$ & Pinning: male vehicle, male AM281, male AM630 & $F(2,187)=5.483, p=0.005$ & Normal & ANOVA & 0.845 \\
\hline $\mathrm{i}$ & Pinning: male vehicle, male AM281 & $p=0.675$ & & Tukey post hoc & -0.4573 to 0.2162 \\
\hline j & Pinning: male vehicle, male AM630 & $p=0.004$ & & Tukey post hoc & -0.7868 to -0.1227 \\
\hline $\mathrm{k}$ & Number of gridlines crossed: male vehicle, male AM281, male AM630 & $F(2,21)=1.150, p=0.339$ & Normal & ANOVA & 0.221 \\
\hline I & Time spent in the center zone: male vehicle, male AM281, male AM630 & $F(2,21)=1.568, p=0.236$ & Normal & ANOVA & 0.289 \\
\hline $\mathrm{m}$ & $\begin{array}{l}\text { Total play: male vehicle, female vehicle, male WIN, female WIN, male } \\
\text { ACEA+GP1a, female ACEA+GP1a }\end{array}$ & $F(2,360)=4.449, p=0.012$ & Normal & $\begin{array}{l}\text { 2-Way ANOVA: sex } \times \\
\text { treatment interaction }\end{array}$ & 0.762 \\
\hline $\mathrm{n}$ & & $F(1,360)=4.108, p=0.043$ & & Main effect of sex & 0.524 \\
\hline 0 & $F(1,360)=2.275, p=0.104$ & Main effect of treatment & & 0.461 & \\
\hline $\mathrm{p}$ & Total play: male vehicle, female vehicle & $t(109.2)=2.666, p=0.0089$ & & $t$-test & 0.5331 to 3.624 \\
\hline$q$ & Total play: female vehicle, female WIN & $t(127.3)=2.01, p=0.0465$ & & $t$-test & 0.023 to 2.919 \\
\hline$r$ & Total play: female vehicle, female ACEA + GP1a & $t(114.7)=2.071, p=0.0406$ & & $t$-test & 0.07583 to 3.415 \\
\hline $\mathrm{s}$ & Total play: male vehicle, female WIN & $t(112.5)=0.7378, p=0.4622$ & & $t$-test & -1.024 to 2.24 \\
\hline$t$ & Total play: male vehicle, female $\mathrm{ACEA}+\mathrm{GP} 1 \mathrm{a}$ & $t(116.8)=0.3607, p=0.719$ & & $t$-test & -1.497 to 2.163 \\
\hline $\mathrm{u}$ & Total play: male vehicle, male WIN & $t(83.32)=0.882, p=0.3803$ & & $t$-test & -1.182 to 3.066 \\
\hline v & Total play: male vehicle, male ACEA+GP1a & $t(109)=1.711, p=0.0899$ & & $t$-test & -3.2 to 0.2348 \\
\hline w & $\begin{array}{l}\text { Pouncing: male vehicle, female vehicle, male WIN, female WIN, male } \\
\text { ACEA+GP1a, female ACEA+GP1a }\end{array}$ & $F(2,359)=6.914, p=0.001$ & Normal & $\begin{array}{l}\text { 2-Way ANOVA: sex } \times \\
\text { treatment interaction }\end{array}$ & 0.923 \\
\hline$\times$ & & $F(1,359)=3.474, p=0.63$ & & Main effect of sex & 0.46 \\
\hline $\mathrm{y}$ & & $F(2,359)=3.7, p=0.026$ & & Main effect of treatment & 0.677 \\
\hline$z$ & Pouncing: male vehicle, female vehicle & $t(118.7)=2.347, p=0.0206$ & & $t$-test & 0.2161 to 2.551 \\
\hline aa & Pouncing: female vehicle, female WIN & $t(131)=1.358, p=0.1767$ & & $t$-test & -0.3653 to 1.966 \\
\hline $\mathrm{bb}$ & Pouncing: female vehicle, female ACEA +GP1a & $t(119.8)=2.123, p=0.0358$ & & t-test & 0.09501 to 2.724 \\
\hline $\mathrm{cc}$ & Pouncing: male vehicle, female WIN & $t(116.3)=0.947, p=0.3456$ & & $t$-test & -0.6366 to 1.803 \\
\hline dd & Pouncing: male vehicle, female ACEA + GP1a & $t(115.3)=0.038, p=0.9698$ & & $t$-test & -1.388 to 1.336 \\
\hline ee & Pouncing: male vehicle, male WIN & $t(77.85)=1.917, p=0.0589$ & & $t$-test & -0.06252 to 3.323 \\
\hline $\mathrm{ff}$ & Pouncing: male vehicle, male ACEA+GP1a & $t(108.9)=2.069, p=0.0409$ & & $t$-test & -2.554 to -0.05488 \\
\hline gg & $\begin{array}{l}\text { Pinning: male vehicle, female vehicle, male WIN, female WIN, male } \\
\text { ACEA+GP1a, female ACEA+GP1a }\end{array}$ & $F(2,329)=3.171, p=0.043$ & Normal & $\begin{array}{l}\text { 2-Way ANOVA: sex } \times \\
\text { treatment interaction }\end{array}$ & 0.605 \\
\hline hh & & $F(1,329)=4.158, p=0.042$ & & Main effect of sex & 0.529 \\
\hline $\mathrm{ii}$ & & $F(2,329)=3.53, p=0.03$ & & Main effect of treatment & 0.655 \\
\hline $\mathrm{jj}$ & Pinning: male vehicle, female vehicle & $t(70.79)=3.206, p=0.002$ & & $t$-test & 0.2814 to 1.207 \\
\hline $\mathrm{kk}$ & Pinning: female vehicle, female WIN & $t(99.25)=5.11, p<0.0001$ & & $t$-test & 0.5536 to 1.256 \\
\hline$\|$ & Pinning: female vehicle, female ACEA+GP1a & $t(89.6)=2.911, p=0.0045$ & & $t$-test & 0.1803 to 0.9554 \\
\hline $\mathrm{mm}$ & Pinning: male vehicle, female WIN & $t(96.71)=0.6144, p=0.5404$ & & $t$-test & -0.6797 to 0.3584 \\
\hline $\mathrm{nn}$ & Pinning: male vehicle, female ACEA+GP1a & $t(103.2)=0.6438, p=0.5211$ & & $t$-test & -0.367 to 0.7198 \\
\hline oo & Pinning: male vehicle, male WIN & $t(94.97)=0.002952, p=0.9977$ & & $t$-test & -0.576 to 0.5777 \\
\hline $\mathrm{pp}$ & Pinning: male vehicle, male ACEA+GP1a & $t(105)=0.4127, p=0.6807$ & & $t$-test & -0.4773 to 0.7281 \\
\hline qq & $\begin{array}{l}\text { Number of gridlines crossed: male vehicle, female vehicle, male } \\
\text { WIN, female WIN, male ACEA+GP1a, female ACEA+GP1a }\end{array}$ & $F(2,45)=2.497, p=0.095$ & Normal & $\begin{array}{l}\text { 2-Way ANOVA: sex } \times \\
\text { treatment interaction }\end{array}$ & 0.471 \\
\hline $\mathrm{rr}$ & & $F(2,45)=0.39, p=0.536$ & & Main effect of sex & 0.094 \\
\hline ss & & $F(1,45)=1.145, p=0.329$ & & Main effect of treatment & 0.237 \\
\hline $\mathrm{tt}$ & $\begin{array}{l}\text { Time spent in the center zone: male vehicle, female vehicle, male } \\
\text { WIN, female WIN, male ACEA+GP1a, female ACEA+GP1a }\end{array}$ & $F(2,45)=0.701, p=0.502$ & Normal & $\begin{array}{l}\text { 2-Way ANOVA: sex } \times \\
\text { treatment interaction }\end{array}$ & 0.16 \\
\hline uu & & $F(1,45)=1.592, p=0.215$ & & Main effect of sex & 0.234 \\
\hline vv & & $F(2,45)=0.936, p=0.401$ & & Main effect of treatment & 0.2 \\
\hline ww & $\begin{array}{l}\text { Total play: male vehicle, female vehicle, male AM281+AM630, } \\
\text { female AM281+AM630 }\end{array}$ & $F(1,240)=7.081, p=0.008$ & Normal & $\begin{array}{l}\text { 2-Way ANOVA: sex } \times \\
\text { treatment interaction }\end{array}$ & 0.755 \\
\hline$x x$ & & $F(1,240)=11.592, p=0.001$ & & Main effect of sex & 0.924 \\
\hline yy & & $F(1,240)=5.207, p=0.023$ & & Main effect of treatment & 0.623 \\
\hline $\mathrm{zz}$ & Total play: male vehicle, female vehicle & $t(126)=4.011, p=0.0001$ & & $t$-test & -9.707 to -3.293 \\
\hline aaa & Total play: male vehicle, male AM281+AM630 & $t(105.5)=3.195, p=0.0018$ & & $t$-test & -8.584 to -2.01 \\
\hline $\mathrm{bbb}$ & Total play: female vehicle, male AM281+AM630 & $t(106.1)=0.7202, p=0.473$ & & $t$-test & -4.515 to 2.109 \\
\hline $\mathrm{ccc}$ & Total play: female vehicle, female AM281+AM630 & $t(106.2)=0.2976, p=7.666$ & & $t$-test & -2.3 to 3.113 \\
\hline ddd & $\begin{array}{l}\text { Pouncing: male vehicle, female vehicle, male AM281+AM630, } \\
\text { female AM281+AM630 }\end{array}$ & $F(1,240)=0.7072, p=0.008$ & Normal & $\begin{array}{l}\text { 2-Way ANOVA: } \operatorname{sex} \times \\
\text { treatment interaction }\end{array}$ & 0.754 \\
\hline eee & & $F(1,240)=13.742, p<0.0001$ & & Main effect of sex & 0.958 \\
\hline fff & & $F(1,240)=6.151, p=0.014$ & & Main effect of treatment & 0.695 \\
\hline ggg & Pouncing: male vehicle, female vehicle & $t(124,9)=4.191, p<0.0001$ & & $t$-test & -7.361 to -2.639 \\
\hline hhh & Pouncing: male vehicle, male AM281+AM630 & $t(107.5)=3.225, p=0.0017$ & & $t$-test & -4.036 to 1.252 \\
\hline iii & Pouncing: female vehicle, male AM281+AM630 & $t(103,6)=0.8051, p=0.4226$ & & $t$-test & -3.337 to 1.41 \\
\hline $\mathrm{jjj}$ & Pouncing: female vehicle, female AM281+AM630 & $t(107.8)=0.1472, p=0.8833$ & & $t$-test & -1.754 to 2.035 \\
\hline kkk & $\begin{array}{l}\text { Pinning: male vehicle, female vehicle, male AM281+AM630, } \\
\text { female AM281+AM630 }\end{array}$ & $F(1,235)=10.073, p=0.002$ & Normal & $\begin{array}{l}\text { 2-Way ANOVA: } \operatorname{sex} \times \\
\text { treatment interaction }\end{array}$ & 0.885 \\
\hline III & & $F(1,235)=1.538, p=0.216$ & & Main effect of sex & 0.235 \\
\hline $\mathrm{mmm}$ & & $F(1,235)=2.716, p=0.101$ & & Main effect of treatment & 0.375 \\
\hline nnn & Pinning: male vehicle, female vehicle & $t(122.1)=3.015, p=0.0031$ & & $t$-test & -2.532 to -0.5248 \\
\hline ০০০ & Pinning: male vehicle, male AM281+AM630 & $t(106.5)=3.251, p=0.0015$ & & $t$-test & -2.687 to -0.6514 \\
\hline $\mathrm{ppp}$ & Pinning: female vehicle, male AM281 + AM630 & $t(101.2)=0.2961, p=0.7678$ & & $t$-test & -0.8049 to 1.087 \\
\hline qqq & Pinning: female vehicle, female AM281+AM630 & $\begin{array}{l}t(121.8)=1.189, p=0.2368 \\
(\text { Continued })\end{array}$ & & $t$-test & -0.3514 to 1.408 \\
\hline
\end{tabular}


Table 1. Continued

\begin{tabular}{|c|c|c|c|c|c|}
\hline Line & Data analyzed & Results & Data structure & Type of test & $\begin{array}{l}\text { Observed power or } \\
\text { confidence interval }\end{array}$ \\
\hline rrr & $\begin{array}{l}\text { Number of gridlines crossed: male vehicle, female vehicle, male } \\
\text { AM281+AM630, female AM281+AM630 }\end{array}$ & $F(1,32)=0.119, p=0.733$ & Normal & $\begin{array}{l}\text { 2-Way ANOVA: } \operatorname{sex} \times \\
\text { treatment interaction }\end{array}$ & 0.063 \\
\hline sss & & $F(1,32)=0.001, p=0.872$ & & Main effect of sex & 0.05 \\
\hline $\mathrm{ttt}$ & & $F(1,32)=0.071, p=0.792$ & & Main effect of treatment & 0.058 \\
\hline uuu & $\begin{array}{l}\text { Time spent in the center zone: male vehicle, female vehicle, male } \\
\text { AM281+AM630, female AM281+AM630 }\end{array}$ & $F(1,32)=0.377, p-0.544$ & Normal & $\begin{array}{l}\text { 2-Way ANOVA: sex } \times \\
\text { treatment interaction }\end{array}$ & 0.091 \\
\hline vvv & & $F(1,32)=0.008, p=0.93$ & & Main effect of sex & 0.051 \\
\hline www & & $F(1,32)=0.406, p=0.529$ & & Main effect of treatment & 0.094 \\
\hline$x x x$ & PN4 cell body area, left hemisphere: male, female & $t(56.06)=0.0325, p=0.0325$ & Normal & $t$-test & -311.4 to -14.03 \\
\hline yyy & PN4 cell body area, right hemisphere: male, female & $t(48.57)=2.088, p=0.042$ & Normal & $t$-test & -353 to -6.739 \\
\hline$z z z$ & PN4 number of dendrites, left hemisphere: male, female & $t(73.5)=0.9388, p=0.3509$ & Normal & $t$-test & -1.024 to 0.368 \\
\hline aaaa & PN4 number of dendrites, right hemisphere: male, female & $t(68.86)=1.385, p=0.1705$ & Normal & $t$-test & -0.2165 to 1.2 \\
\hline bbbb & PN4 number of nodes, left hemisphere: male, female & $t(73.09)=0.9446, p=0.348$ & Normal & $t$-test & -1.935 to 0.6905 \\
\hline $\operatorname{cccc}$ & PN4 number of nodes, right hemisphere: male, female & $t(71.89)=0.643, p=0.5223$ & Normal & $t$-test & -0.5776 to 1.128 \\
\hline dddd & PN4 spine density, left hemisphere: male, female & $t(72.17)=0.2635, p=0.7929$ & Normal & $t$-test & -0.01184 to 0.01545 \\
\hline eeee & PN4 spine density, right hemisphere: male, female & $t(72.52)=0.06693, p=0.9468$ & Normal & $t$-test & -0.01593 to 0.01489 \\
\hline ffff & PN4 total dendrite length, left hemisphere: male, female & $t(74)=1.527, p=0.1309$ & Normal & $t$-test & -64.47 to 8.518 \\
\hline gggg & PN4 total dendrite length, right hemisphere: male, female & $t(72.09)=0.2125, p=0.8323$ & Normal & $t$-test & -28.12 to 34.83 \\
\hline hhhh & PN4 average dendrite length, left hemisphere: male, female & $t(71.66)=1.452, p=0.1509$ & Normal & $t$-test & -14.13 to 2.221 \\
\hline iiii & PN4 average dendrite length, right hemisphere: male, female & $t(71.1)=0.82898, p=0.4094$ & Normal & $t$-test & -11.26 to 4.641 \\
\hline \multicolumn{6}{|c|}{ PN26 factor analysis: sex differences in neuronal morphology } \\
\hline jjjj & Factor 1 , left hemisphere: male, female & $t(40.31)=0.4664, p=0.6435$ & Normal & $t$-test & -0.4694 to 0.7511 \\
\hline kkkk & Factor 1 , right hemisphere: male, female & $t(28.31)=3.454, p=0.0018$ & Normal & $t$-test & -1.479 to -0.378 \\
\hline IIIII & Factor 2, left hemisphere: male, female & $t(43.65)=0.2945, p=0.7698$ & Normal & $t$-test & -0.6725 to 0.5011 \\
\hline $\mathrm{mmmm}$ & Factor 2, right hemisphere: male, female & $t(30.22)=0.7176, p=0.4785$ & Normal & $t$-test & -0.4041 to 0.842 \\
\hline nnnn & Factor 3 , left hemisphere: male, female & $t(42.96)=0.9127, p=0.3665$ & Normal & $t$-test & -0.3008 to 0.798 \\
\hline oooo & Factor 3 , right hemisphere: male, female & $t(46)=1.431, p=0.1592$ & Normal & $t$-test & -0.9151 to 0.1546 \\
\hline \multicolumn{6}{|c|}{ PN26 factor analysis: effects of specific and dual agonism on neuronal morphology } \\
\hline pppp & Factor 1, left hemisphere: female vehicle, female ACEA, female GP1a & $F(2,60)=0.533, p=0.0589$ & Normal & ANOVA & 0.134 \\
\hline qवqव & Factor 1, left hemisphere, female vehicle: female ACEA+GP1a & $t(38.27)=0.4245, p=0.6735$ & Normal & $t$-test & -0.4879 to 0.747 \\
\hline rrrr & Factor 1 , right hemisphere: female vehicle, female ACEA, female GP1a & $F(2,60)=2.099, p=0.132$ & Normal & ANOVA & 0.414 \\
\hline ssss & Factor 1 , right hemisphere: female vehicle, female ACEA+GP1a & $t(37.95)=1.639, p=0.1094$ & Normal & $t$-test & -1.193 to 0.1255 \\
\hline $\mathrm{tttt}$ & $\begin{array}{l}\text { Factor 2, left hemisphere: female vehicle, female ACEA, female GP1a } \\
\text { left hemisphere: female vehicle, female ACEA, female GP1a }\end{array}$ & $F(2,60)=2.576, p=0.085$ & Normal & ANOVA & 0.494 \\
\hline unuu & Factor 2, left hemisphere: female vehicle, female ACEA+GP1a & $t(36.6)=0.2349, p=0.8156$ & Normal & $t$-test & -0.5315 to 0.6708 \\
\hline vvvv & Factor 2, right hemisphere: female vehicle, female ACEA, female GP1a & $F(2,60)=0.235, p=0.791$ & Normal & ANOVA & 0.085 \\
\hline wwww & Factor 2, right hemisphere: female vehicle, female ACEA+GP1a & $t(39.38)=1.888, p=0.0664$ & Normal & $t$-test & -0.03766 to 1.099 \\
\hline \multicolumn{6}{|c|}{ PN26 dual agonism masculinizes neuronal morphology } \\
\hline$x x x x$ & Factor 1, left hemisphere: male vehicle, female vehicle, female ACEA+GP1a & $F(2,72)=0.257, p=0.774$ & Normal & ANOVA & 0.089 \\
\hline yyyy & Factor 1 , right hemisphere: male vehicle, female vehicle, female ACEA+GP1a & $F(2,72)=5.689, p=0.005$ & Normal & ANOVA & 0.849 \\
\hline zzzz & Factor 1 , right hemisphere: male vehicle, female vehicle & $p=0.008$ & & Tukey's Post-hoc & -1.3958 to -0.1738 \\
\hline aaaaa & Factor 1, right hemisphere: female vehicle, female ACEA+GP1a & $p=0.012$ & & Tukey's post hoc & 0.1473 to 1.4254 \\
\hline bbbbb & Factor 1 , right hemisphere: male vehicle, female ACEA+GP1a & $p=1.000$ & & Tukey's post hoc & -0.5597 to 0.5628 \\
\hline $\operatorname{ccccc}$ & Factor 2, left hemisphere: male vehicle, female vehicle, female ACEA+GP1a & $F(2,72)=0.956, p=0.775$ & Normal & ANOVA & 0.089 \\
\hline ddddd & Factor 2, right hemisphere: male vehicle, female vehicle, female ACEA+GP1a & $F(2,72)=1.991, p=0.144$ & Normal & ANOVA & 0.398 \\
\hline
\end{tabular}

total number of play events ${ }^{f}$ (Fig. $5 A, B$ ) or the number of pounces $^{9}$ (Fig. 6A, B). However, CB2R antagonism increased the number of pins ${ }^{\mathrm{h}, \mathrm{j}}$ (Fig. 7A, B). Neither AM281 nor AM630 altered the number of gridlines crossed ${ }^{k}$ or the time spent in the center of an open field' (data not shown).

\section{Effects of combined CB1R or CB2R receptor agonism during early development on juvenile rough-and-tumble play behavior}

Because of the surprising lack of changes to juvenile social play behavior after either specific agonism or antagonism of CB1R and CB2R, we administered a combination of ACEA and GP1a or WIN55,212-2 to neonatal (PNO-3) males and females to determine whether the combination of specific agonists would recapitulate the previous findings on the effect of treatment with WIN55,212-2. When assessed for the total number of juvenile rough-and-tumble play events, there was a significant interaction between sex and drug treatment ${ }^{m}$, with a main effect of sex ${ }^{n}$, but no main effect of treatment ${ }^{\circ}$ (Fig. 2C-E).

A priori post hoc $t$-tests were used to address our hypothesis that males would have a higher total number of play events than females. Neonatal treatment with WIN55,212-2 and ACEA+GP1a were predicted to increase female play to the level observed in males, and neither WIN55,212-2 nor ACEA+GP1a was predicted to alter male play. As expected, vehicle-treated males played more than vehicle-treated females ${ }^{\mathcal{p}}$ (Fig. $2 C-E$; see Movie 1 and Movie 2 for a comparison of typical male and female rough-and-tumble play behavior, respectively). Neonatal treatment of females with both WIN55,212-2 and ACEA+GP1a increased the number of play events relative to control females ${ }^{q, r}$ (Fig. 2C,D). WIN55,212-2and ACEA+GP1a-treated females and males all demonstrated a number of play events comparable to that of vehicle-treated males ${ }^{\mathrm{s}, \mathrm{t}, \mathrm{u}, \mathrm{v}}$ (Fig. $2 C-E$ ).

To determine the effects of neonatal treatment with WIN55,212-2 and ACEA+GP1a on initiation of play and response to play initiation, the total number of play events was split into pounces and pins. There was a significant sex $\times$ treatment interaction ${ }^{w}$ with a main effect of treatment $^{y}$, but no main effect of sex for pouncing (Fig. 3C-E) and a significant sex $\times$ treatment $^{99}$ interaction with main effects of both sex ${ }^{\text {hh }}$ and treatment ${ }^{\text {ti }}$ for pinning (Fig. $4 C-E)$. 

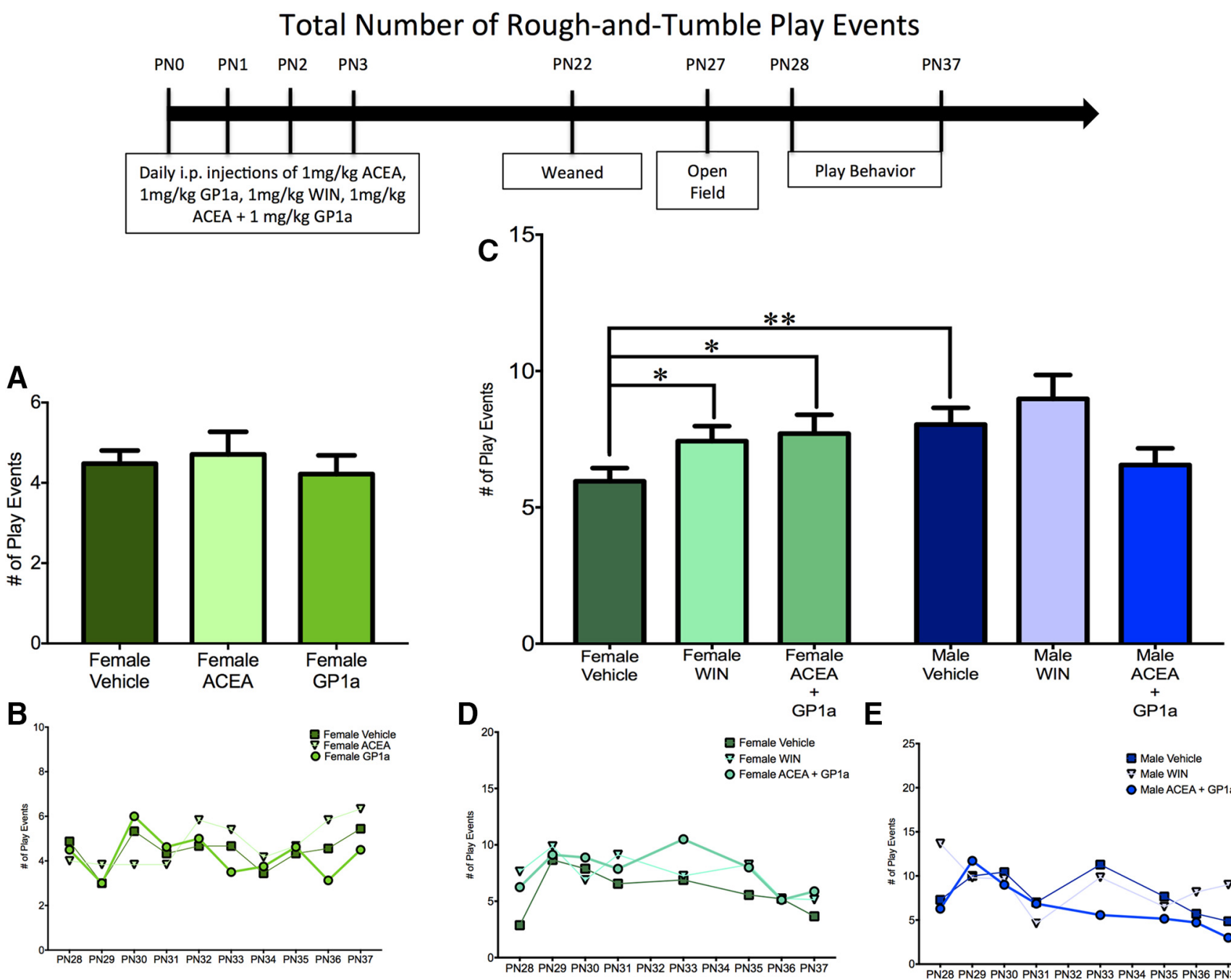

E

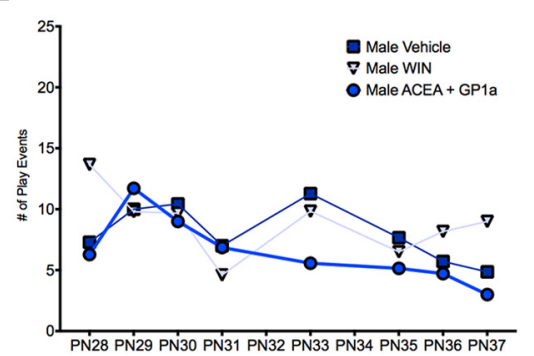

Fig. 2. Activation of both $\mathrm{CB} 1 \mathrm{R}$ and $\mathrm{CB} 2 \mathrm{R}$ is necessary to masculinize the total frequency of female play behavior. $\boldsymbol{A}, \boldsymbol{B}, \mathrm{Administration}$ of ACEA (a CB1-specific agonist) or GP1a (a CB2-specific agonist) to neonatal (PNO-3) females did not alter the total frequency of juvenile rough-and-tumble play behavior (total of all pouncing, pinning, and boxing events from PN28-37). $\boldsymbol{C}-\boldsymbol{E}$, Neonatal administration of WIN55,212-2 (WIN, a nonspecific endocannabinoid receptor agonist) or coadministration of ACEA and GP1a increased the frequency of play by juvenile females to the level observed in males but did not cause a further increase in male play. $\boldsymbol{B}, \boldsymbol{D}, \boldsymbol{E}$, Insets show the average frequency of rough-and-tumble play events for each day of analysis. $* p<0.05, * * p<0.01, n=6-9$.

Control males had higher levels of both pouncing ${ }^{2}$ and pinning ${ }^{\mathrm{jj}}$ relative to females (Figs. $3 C-E$ and $4 C-E$ ). Neonatal treatment with WIN55,212-2 increased pinning ${ }^{\mathrm{kk}}$ in females, but did not alter pouncing aa, whereas treatment with ACEA+GP1a increased both pouncing ${ }^{\mathrm{bb}}$ and pinning" (Figs. $3 C, D$ and $4 C, D$ ). Both pouncing ${ }^{\mathrm{cc}, \mathrm{dd}}$ and pinning $^{\mathrm{mm}, \mathrm{nn}}$ behavior of WIN55,212-2- and ACEA+GP1atreated females was indistinguishable from that of vehicle-treated males (Figs. $3 C-E$ and $4 C-E$ ). Although there were no changes in total play in males after neonatal treatment with WIN55,212-2 and ACEA+GP1a, there was a decrease in pouncing in ACEA+GP1a-treated males ${ }^{\text {ff }}$ (Fig. $3 C, E$ ). During the open field test neither prior drug treatment (ACEA+GP1a or WIN55,212-2) nor the sex of the animal influenced the number of gridlines crossed $^{q \mathrm{q}, \mathrm{r}, \mathrm{ss}}$ or time spent in the center zone ${ }^{\mathrm{tt}, \mathrm{uu}, \mathrm{vv}}$ of the open field (data not shown).
Effects of combined CB1R or CB2R antagonism during early development on juvenile rough-andtumble play behavior

After determining that only combined agonism of CB1R and CB2R was sufficient to masculinize social play by females, we hypothesized that combined antagonism of CB1R and CB2R would dysmasculinize social play behavior in males. Additionally, based on the finding that combined agonism of CB1R and CB2R did not alter juvenile male behavior, we hypothesized that combined antagonism of CB1R and CB2R would have no effect on juvenile female play behavior. Neonatal (PNO-3) males and females were treated with AM281 and AM630. For total numbers of juvenile rough-and-tumble play events, there was a significant sex by treatment interaction ${ }^{w w}$, with a main effect of sex $^{\mathrm{xx}}$ and treatment ${ }^{\mathrm{yy}}$ (Fig. 5C-E). As observed previously, vehicle-treated males played more 


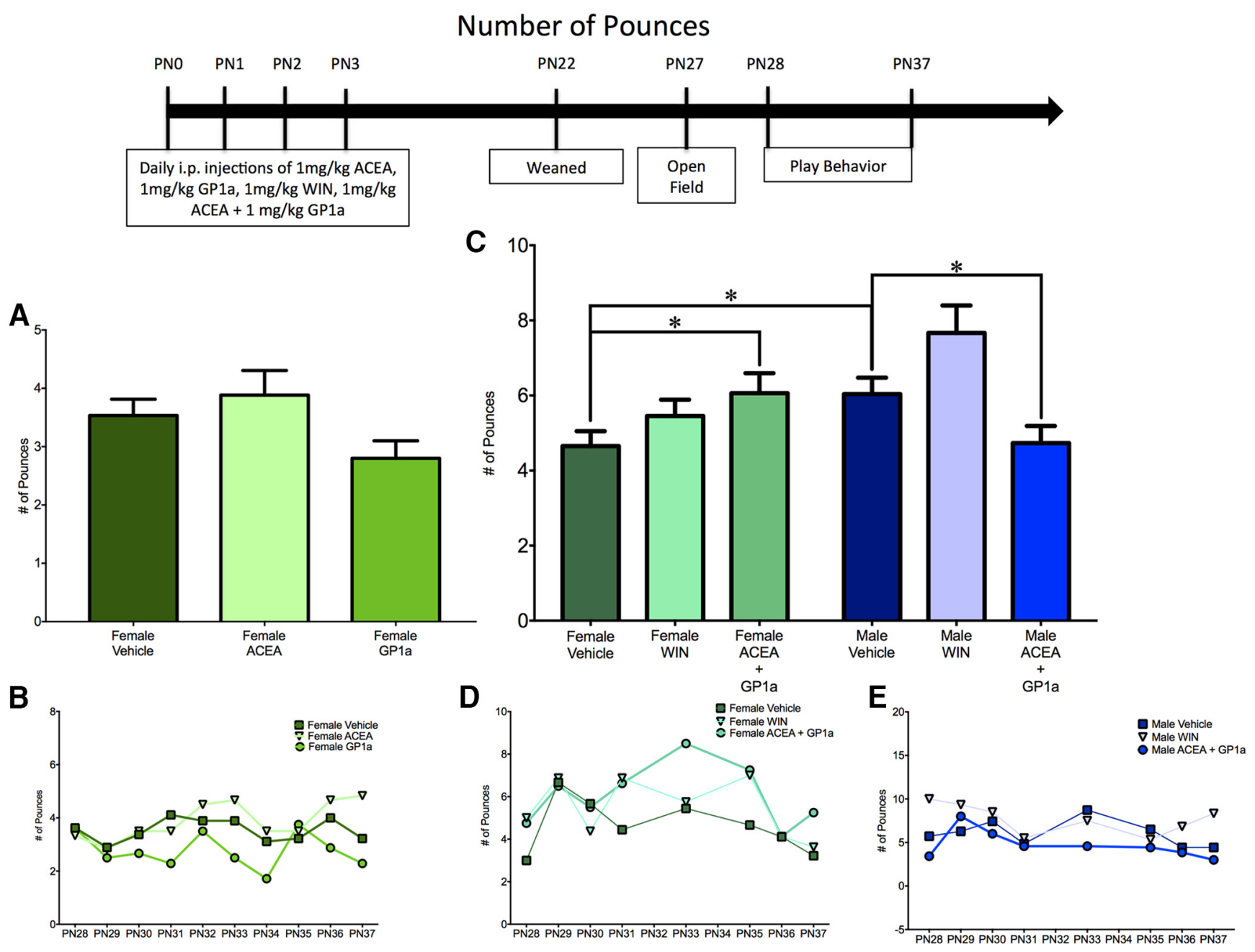

Fig. 3. Activation of both $\mathrm{CB} 1 \mathrm{R}$ and $\mathrm{CB} 2 \mathrm{R}$ is necessary to masculinize female pouncing behavior. $\boldsymbol{A}, \boldsymbol{B}$, Administration of $A C E A, \mathrm{GP} 1 \mathrm{a}$, or WIN to neonatal (PNO-3) females did not alter the frequency of pouncing events. $\boldsymbol{C}-\boldsymbol{E}$, Neonatal coadministration of ACEA and GP1a increased female pouncing and decreased male pouncing. Frequency of pouncing is an average over all days of analysis with the average for each individual day shown in the insets $(\boldsymbol{B}, \boldsymbol{D}, \boldsymbol{E}) . * p<0.05, n=6-9$.

than vehicle-treated females ${ }^{\mathrm{zZ}}$ (Fig. $\left.5 C-E\right)$. In support of our hypothesis, AM281 + AM60-treated males played less than vehicle-treated males ${ }^{\text {aaa }}$ and were analogous to

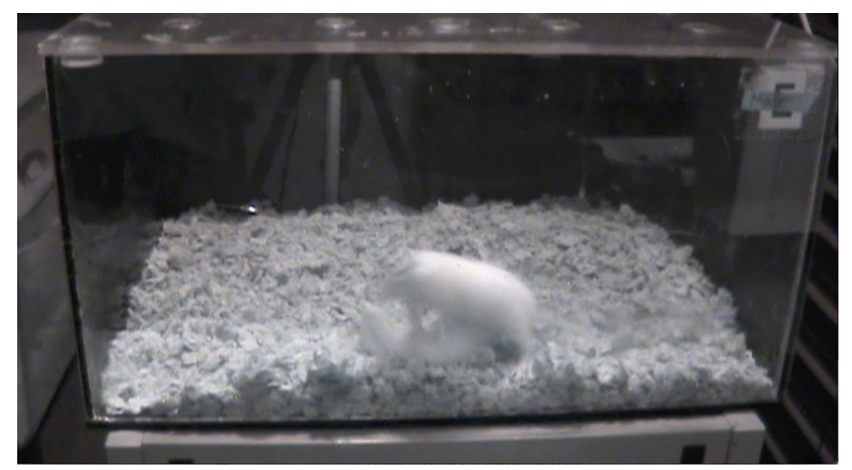

Movie 1. Representative example of male juvenile social play behavior. Two juvenile males (PN28) were allowed to acclimate to the chamber for 2 minutes, after which video recording was initiated. Instances of pouncing, pinning, and boxing were recorded from time 0 to 10:00. vehicle-treated females $^{\text {bbb }}$ (Fig. 5C-E). As predicted, AM281+AM630-treated females were equivalent to vehicle-treated females $^{\mathrm{ccc}}$ (Fig. 5C, E).

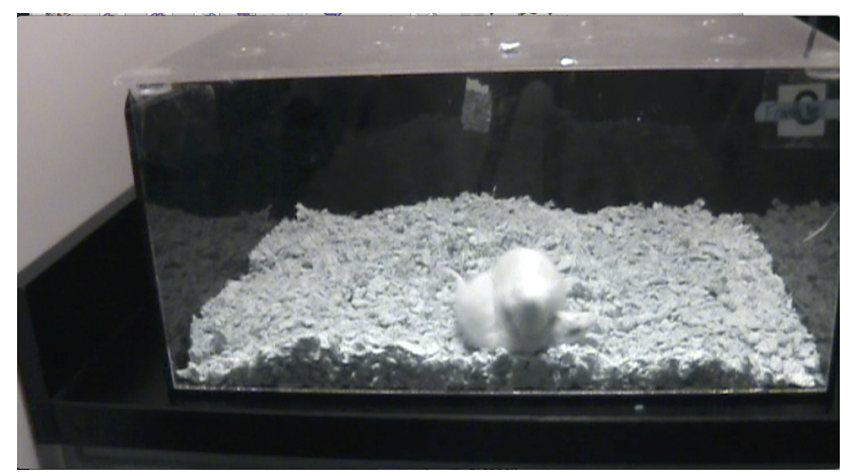

Movie 2. Representative example of female juvenile social play behavior. Two juvenile females (PN28) were allowed to acclimate to the chamber for 2 minutes, after which video recording was initiated. Instances of pouncing, pinning, and boxing were recorded from time 0 to 10:00. 


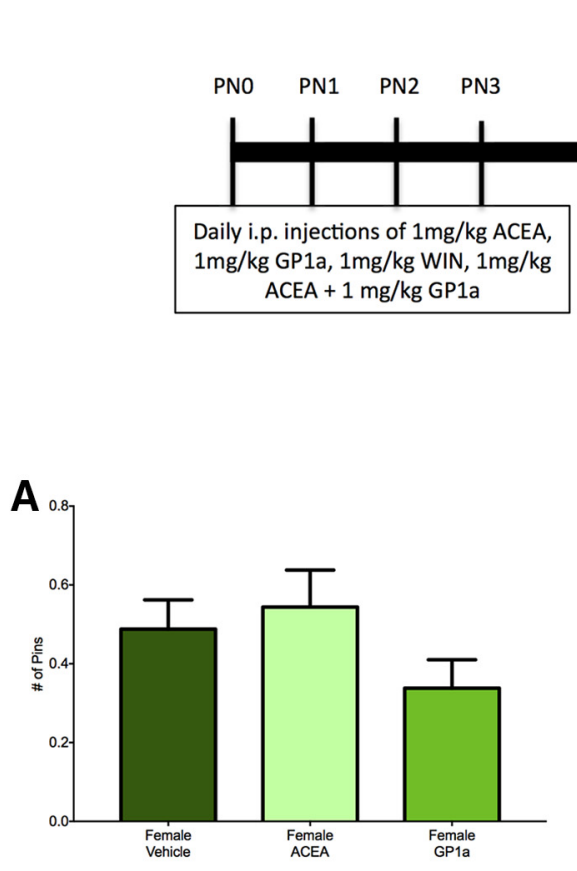

\section{Number of Pins}
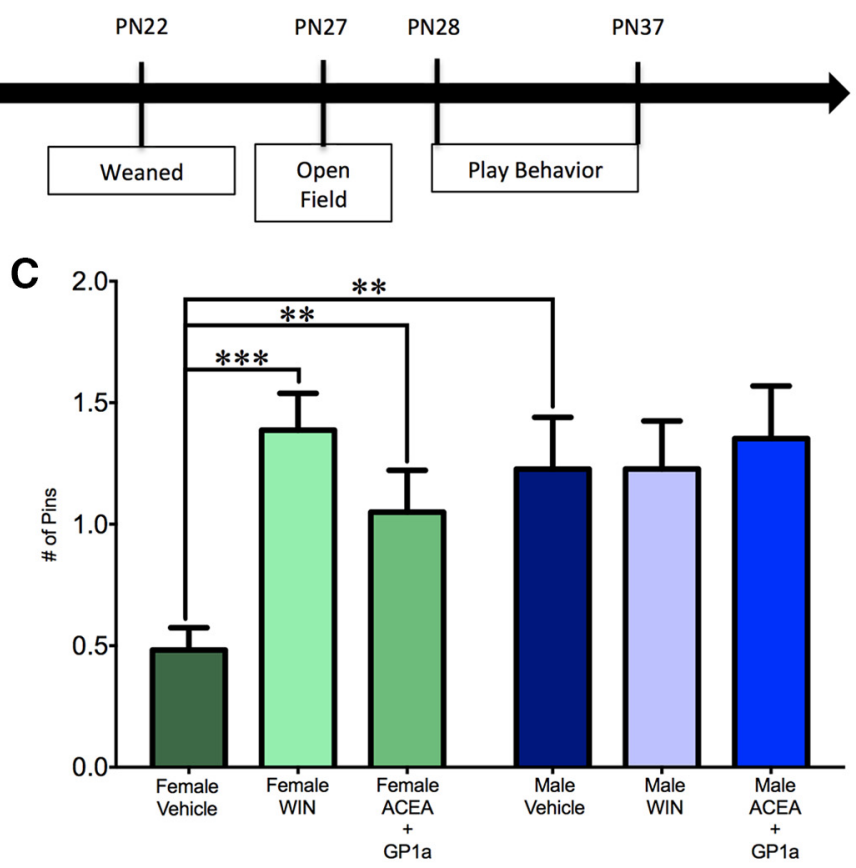

B

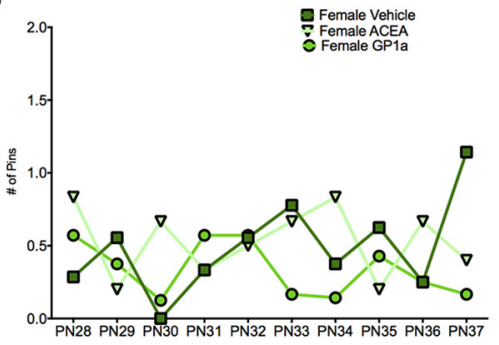

D

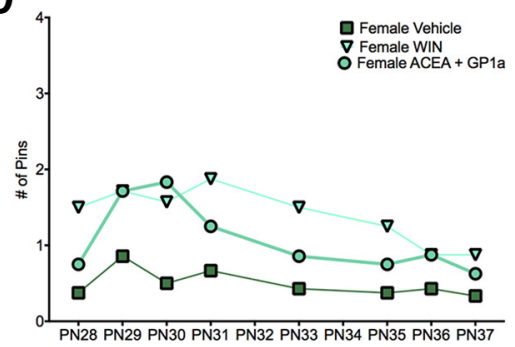

E

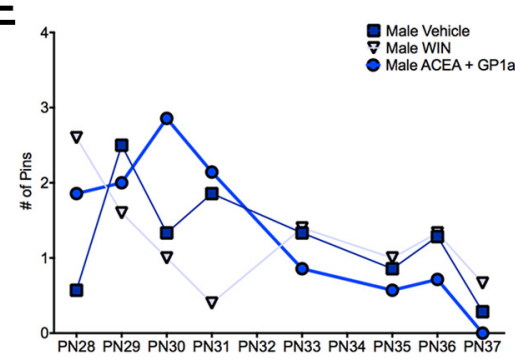

Fig. 4. Activation of both $\mathrm{CB} 1 \mathrm{R}$ and $\mathrm{CB} 2 \mathrm{R}$ is necessary to masculinize female pinning behavior. $\boldsymbol{A}, \boldsymbol{B}$, Administration of $\mathrm{ACEA}$ or GP1a to neonatal (PNO-3) females did not alter the frequency of pinning events. $\boldsymbol{C}-\boldsymbol{E}$, Neonatal coadministration of ACEA and GP1a or treatment with WIN increased the frequency of pinning by females to the level observed in males and had no effect on male pinning behavior. Frequency of pinning is an average over all days of analysis with the average for each individual day shown in the insets $(\boldsymbol{B}, \boldsymbol{D}, \boldsymbol{E}) . * * p<0.01, * * * p<0.001, n=6-9$.

A breakdown of total play into pouncing and pinning resulted in an interaction between sex and treatment for both pouncing ${ }^{\text {ddd }}$ and pinning ${ }^{\mathrm{kkk}}$, as well as main effects of sex and treatment for pouncing ${ }^{\text {eee,fff }}$ but not pinning ${ }^{11, m m m}$ (Figs. $6 C-E$ and $7 C-E$ ). A priori post hoc $t$-test confirmed our hypotheses that juvenile males pouncedggg and pinned more than females ${ }^{\mathrm{nn}}$, but males treated neonatally with AM281+AM630 pounced and pinned less than control males $^{\text {hhh, }}, 000$ and were comparable to control femalesiii,ppp (Figs. $6 C-E$ and $7 C-E$ ). Neonatal treatment with AM281+ AM630 did not alter female pouncing ${ }^{\mathrm{iji}}$ or pinning ${ }^{\text {qqa }}$ behaviors (Figs. 6C, E and 7C, E). Treatment with AM281+AM630 in males or females did not alter the number of gridlines crossed ${ }^{r r r, s s s, t t t}$ or the amount of time spent in the center zone ${ }^{\text {uuu, vvv,www }}$ of the open field on PN26 (data not shown).

\section{Sex differences in neuronal morphology in the neonatal medial amygdala}

We first investigated neuronal morphology at PN4 to determine whether sex differences were present during the time of our manipulation of the endocannabinoid system, which also corresponds with the sensitive period for sexual differentiation of neuronal circuitry. In the preoptic area, ventromedial nucleus, and arcuate nucleus of the hypothalamus, sex differences in neuronal morphology are already present at this age (Mong et al., 1999; Amateau and McCarthy, 2004). 3D reconstruction of Golgiimpregnated neurons in the medial amygdala indicated that males have larger cell bodies in both the right and left hemispheres ${ }^{\mathrm{xx}}$, yyy relative to females, but there were no sex differences in numbers of dendrites ${ }^{\mathrm{zzz} \text {, aaaa }}$ or nodes ${ }^{\text {bbbb, cccc}}$, spine density ${ }^{\text {dddd, eeee }}$, or total ${ }^{\text {ffff, }}$ gggg and average ${ }^{\text {hhhh, }}$ iiii dendrite length (Fig. 8).

\section{Sex differences in neuronal morphology in the juvenile medial amygdala}

We next investigated sex differences in neuronal morphology at PN26. Cell body area, number of dendrites, number of nodes, spine density, average dendritic length, and total dendritic length were analyzed by factor analysis 

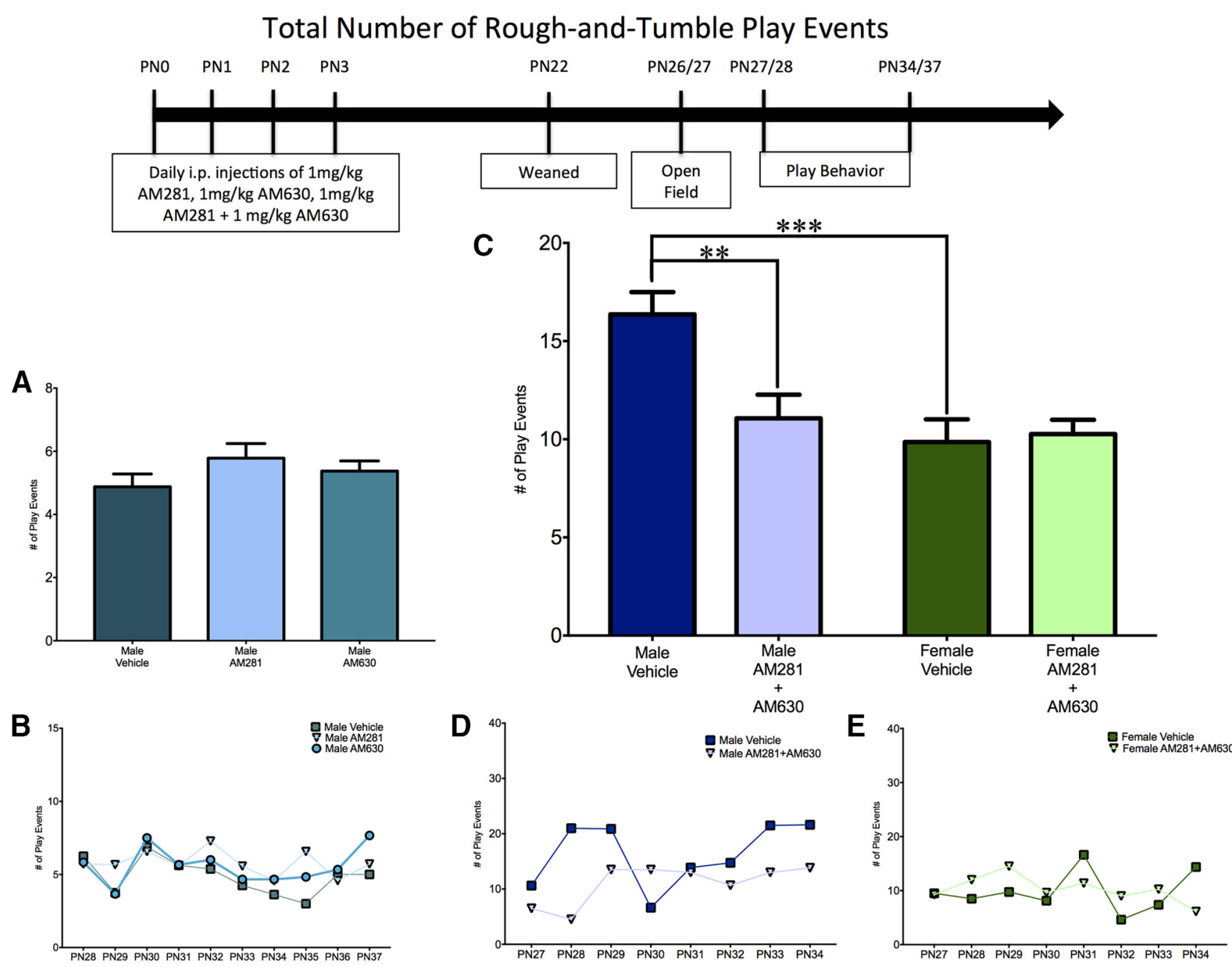

Fig. 5. Combined antagonism of $\mathrm{CB} 1 \mathrm{R}$ and $\mathrm{CB} 2 \mathrm{R}$ is necessary to feminize the total frequency of male play behavior. $\boldsymbol{A}$, $\boldsymbol{B}$, Administration of AM281 (a CB1-specific antagonist) or AM630 (a CB2-specific antagonist) to neonatal males (PN0-3) did not alter the total frequency of rough-and-tumble play events. $\boldsymbol{C}-\boldsymbol{E}$, Coadministration of AM281 and AM630 decreased the total frequency of rough-and-tumble play events by males to the level observed in females and had no effect on female play. Frequency of play is an average over all days of analysis, with the average for each individual day shown in the insets $(\boldsymbol{B}, \boldsymbol{D}, \boldsymbol{E})$. **p $<0.01, * * * p<0.001$, $n=6-10$.

to identify patterns in how these parameters contributed to differences in neuronal morphology. Factor analysis identified three factors, together accounting for $73.9 \%$ of total variance, that were sufficient to explain the data. The first factor, which accounted for $34 \%$ of the total variance and was named Neuronal Complexity, contained positive loadings for number of nodes, total dendritic length, and average dendritic length. The second factor, which accounted for $23.1 \%$ of the total variance and was named Dendritic Field, contained positive loadings for the number of dendrites and total dendritic length and a negative loading for average dendritic length. The third factor, which accounted for $16.8 \%$ of the total variance and was named Spine Density, contained a positive loading for a single parameter, spine density (Fig. 10A).

To determine how these factors corresponded to visual observations of differences in neuronal morphology, neurons from males and females were separated into three different classifications based on the classes used by Nishizuka et al. (1989). Type I neurons were defined based on the presence of a spindle-shaped cell body and one to three primary dendrites with numerous spines branching into a cylindrical field. We did not find any neurons belonging to the Type II class that were described as almost entirely lacking dendritic spines (Nishizuka et al., 1989). Type III neurons had ovoid cell bodies and two to five dendrites with some spines. Type IV neurons had three to five dendrites and were distinguished from Type III neurons based on their high spine density. Data points corresponding to individual neurons were color- and shapecoded based on their classification as Type I, III, or IV and graphed according to their factor scores for Dendritic Complexity and Dendritic Field (Fig. 9). The resulting scatter plot shows a clear linear separation of data points along the $y$-axis, corresponding to the scores for Dendritic Field. The grouping of points along this axis was attrib- 


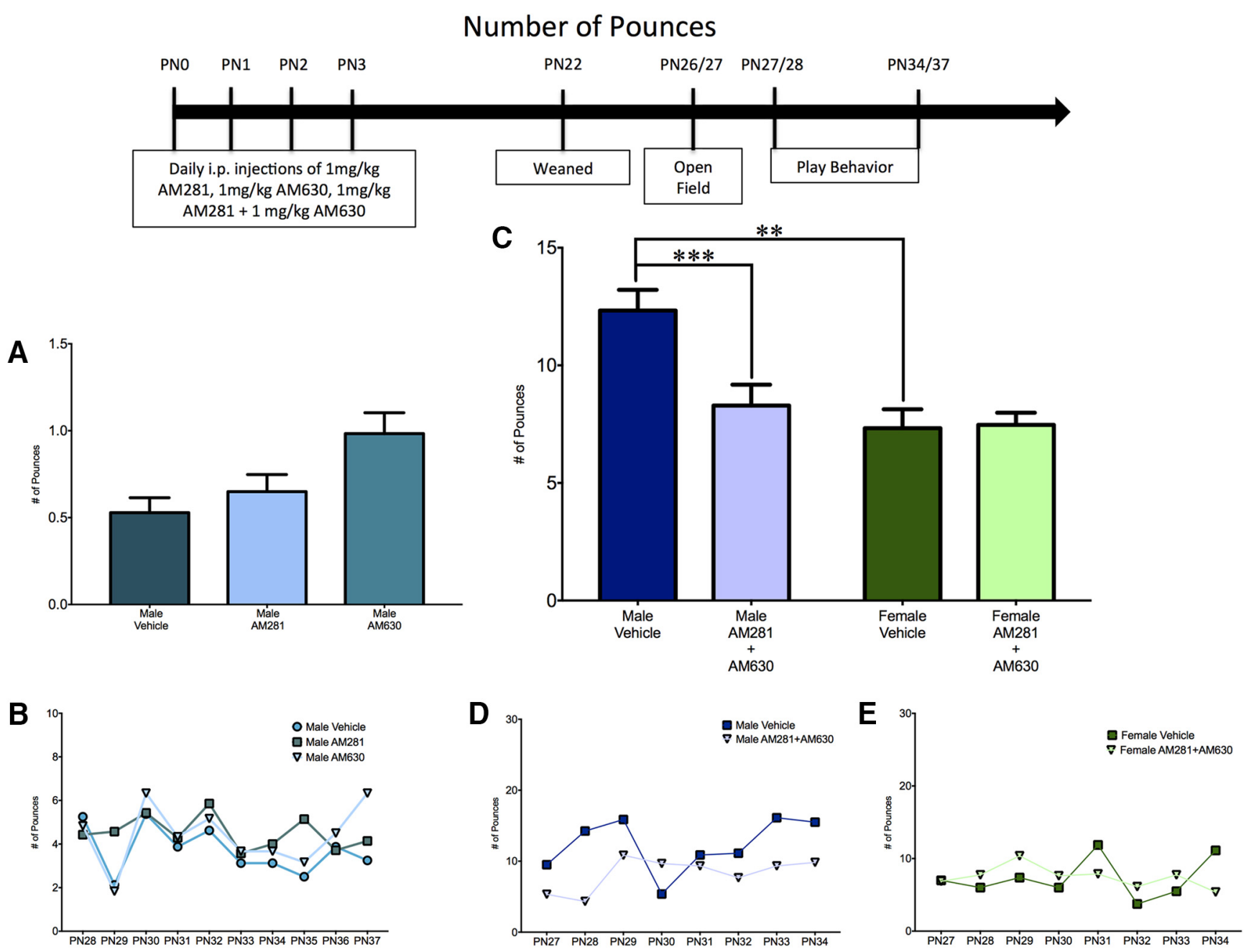

Fig. 6. Combined antagonism of $C B 1 R$ and $C B 2 R$ is necessary to feminize pouncing behavior by males. $A, B$, Administration of $A M 281$ or AM630 to neonatal males (PN0-3) did not alter the frequency of pouncing behavior. $\boldsymbol{C}-\boldsymbol{E}$, Coadministration of AM281 and AM630 decreased pouncing behavior by males to the level observed in females and had no effect on female play. Frequency of pouncing is an average over all days of analysis, with the average for each individual day shown in the insets $(\boldsymbol{B}, \boldsymbol{D}, \boldsymbol{E}) . * * p<0.01, * * * p<0.001, n=6-10$.

uted to the fact that all neurons must have at least one dendrite, making it impossible for a data point to fall at a position that would correspond to zero dendrites or fractions of dendrites. We chose a representative tracing of a neuron for each quadrant of the graph to illustrate that neurons with high factor scores for Dendritic Complexity and Dendritic Field (quadrant 1) were the most complex neurons, with several long dendrites and multiple branch points; neurons with high scores for Dendritic Complexity and low scores for Dendritic Field (quadrant 4) had few long dendrites with moderate branching; neurons with a low Dendritic Complexity score and a high Dendritic Field score (quadrant 3) had several dendrites that were relatively short with minimal branching; and neurons with low Factor 1 and Factor 2 scores (quadrant 2) had few short dendrites with minimal branching (Fig. 9). Neurons that we classified as Type I grouped together within quadrants 3 and 4 on the graph, Type III neurons grouped within quadrants 2 and 4 on the graph, and Type IV neurons grouped mostly within quadrant 1 (Fig. 9).
To quantify sex differences in these three factors, we calculated and compared factor scores for neurons from females and males in both the right and left hemisphere. For Dendritic Complexity, males and females were not different in the left hemisphere $\mathrm{e}^{\mathrm{ijij}}$; however, females had higher factor scores in the right hemisphere ${ }^{\mathrm{k} k \mathrm{k}}$, suggesting that females have greater dendritic complexity in the right hemisphere relative to males (Fig. 10B). For Dendritic Field and Spine Density, males and females did not differ significantly in

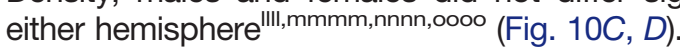

\section{Comparison of neonatal select or dual agonism of CB1R and CB2R on neuronal morphology in the juvenile medial amygdala}

Factor analysis accounted for $60.7 \%$ of the total variance (Fig. 11A). Dendritic Complexity accounted for $29.9 \%$ of the variance, whereas Dendritic Field explained $25.6 \%$ of the total variance. Spine Density accounted for $5.2 \%$ of the total variance and was excluded from further analysis. We calculated factor scores for neurons from the 

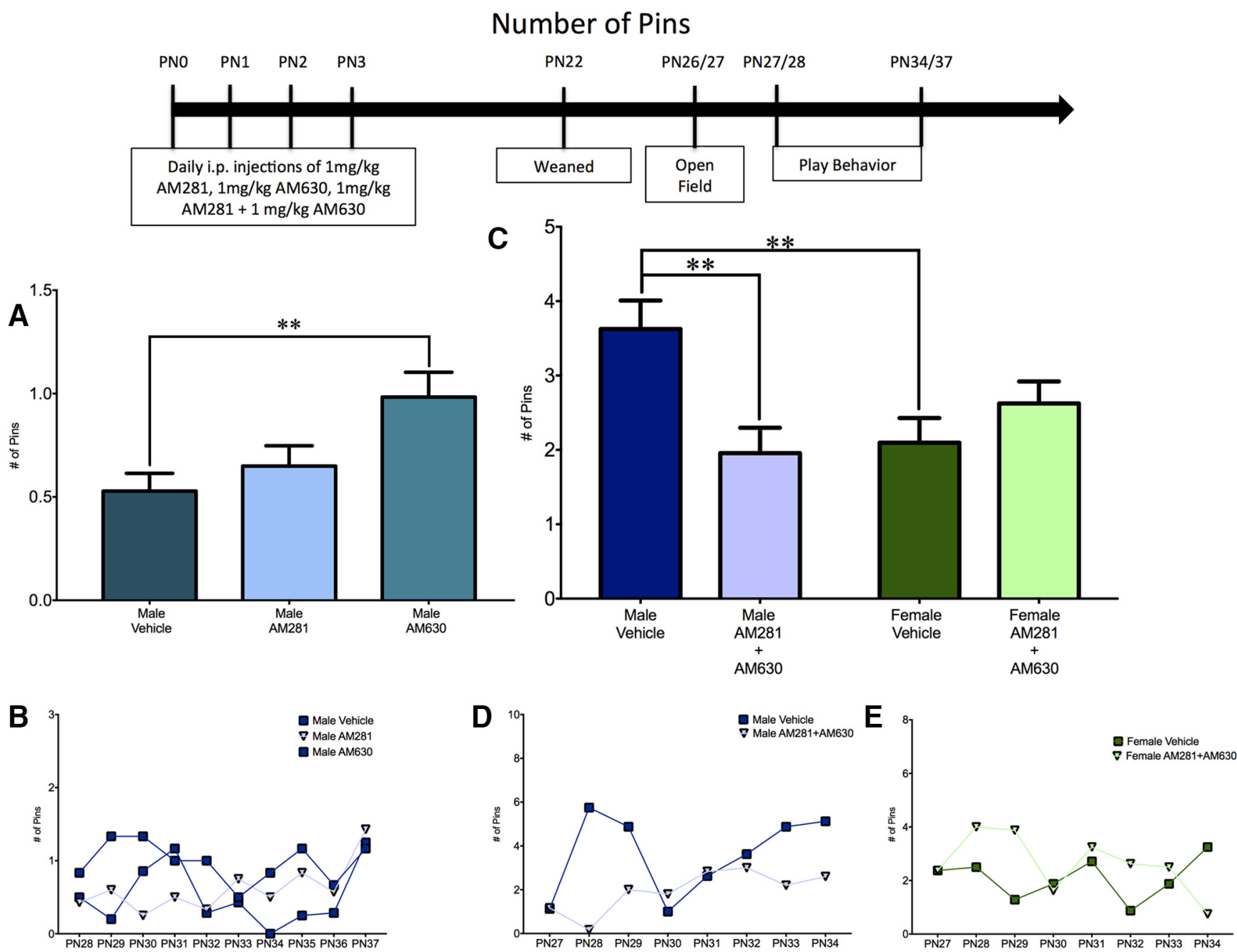

Fig. 7. Combined antagonism of $\mathrm{CB} 1 \mathrm{R}$ and $\mathrm{CB} 2 \mathrm{R}$ is necessary to feminize pinning behavior by males. $\boldsymbol{A}, \boldsymbol{B}$, Administration of $\mathrm{AM} 281$ to neonatal males (PN0-3) did not alter the frequency of pinning behavior, whereas treatment with AM630 caused an increase in pinning. $\boldsymbol{C}-\boldsymbol{E}$, Coadministration of AM281 and AM630 decreased pinning behavior by males to the level observed in females and had no effect on female play. Frequency of pinning is an average over all days of analysis, with the average for each individual day shown in the insets $(\boldsymbol{B}, \boldsymbol{D}, \boldsymbol{E})$. $* * p<0.01, n=6-10$.

right and left hemisphere from each treatment group. For Dendritic Complexity, there was no effect of specific or dual agonism in either hemisphere ${ }^{\text {pppp, qqqq, rrrr, ssss }}$ (Fig. $11 B$ ). For Dendritic Field in the left hemisphere, there was a slight trend toward a significant effect of select agonism $^{\text {tttt }}$ and no effect of dual agonism ${ }^{\text {uuuu }}$, whereas in the right hemisphere there was no effect of select agonism ${ }^{v v v v}$ and a trend toward a significant effect of dual ago$n^{n i s m}{ }^{w w w w}$ (Fig. 11C). These trends in the data suggest a shift in morphology toward a decreased dendritic field size in the left hemisphere after neonatal specific agonism and a shift toward a larger dendritic field in the right hemisphere after neonatal dual agonism.

\section{Neonatal dual agonism of CB1R and CB2R masculinizes neuronal morphology in the juvenile medial amygdala}

Factor analysis identified three factors that accounted for $67.8 \%$ of the total variance. This included Dendritic Field and Dendritic Complexity as before, but a new factor was added named Nodes, which contained positive loading for number of nodes but was excluded from further analysis (Fig. 12A). Dendritic Field accounted for $28 \%$ of the variance, and Dendritic Complexity accounted for $23.7 \%$. For Dendritic Field, there were no differences in the left hemisphere ${ }^{\mathrm{x} \times \mathrm{x}}$, but there was a significant effect in the right hemisphere ${ }^{\mathrm{yyy} y}$ where males had lower factor scores relative to females ${ }^{\mathrm{zzzz}}$, and females treated neonatally with ACEA+GP1 had lower factor scores relative to control females aaaa and were comparable to control males ${ }^{\text {bbbbb }}$. For Dendritic Field, there were no differences in the left hemisphere ${ }^{\mathrm{ccccc}}$, and in the right hemisphere the factor scores showed trends similar to those for Dendritic Complexity, with control females loading higher than control males and ACEA+GP1a-treated females; however, these differences were not significant ${ }^{\text {ddddd }}$.

\section{Discussion}

Social play behavior is engaged in by juveniles but is programmed developmentally during the sensitive period 
PN4 Neuronal Reconstruction

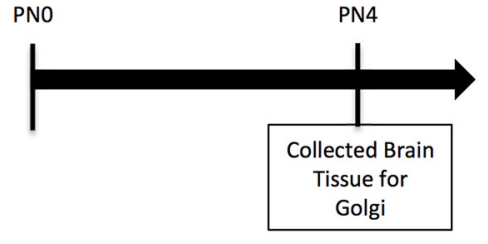

A

Cell Body Area

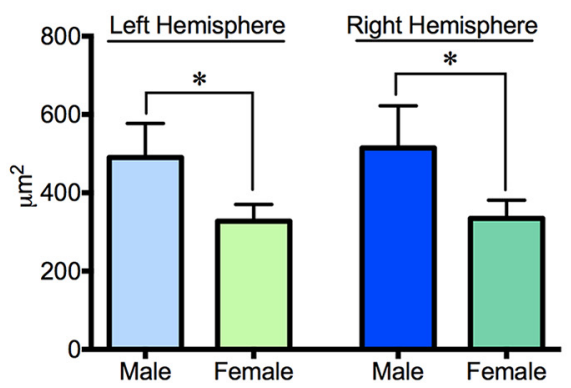

B

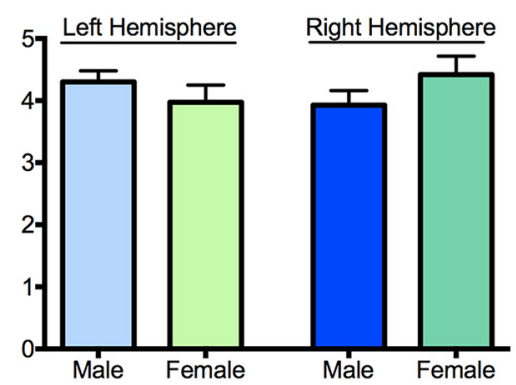

E

Total Dendrite Length

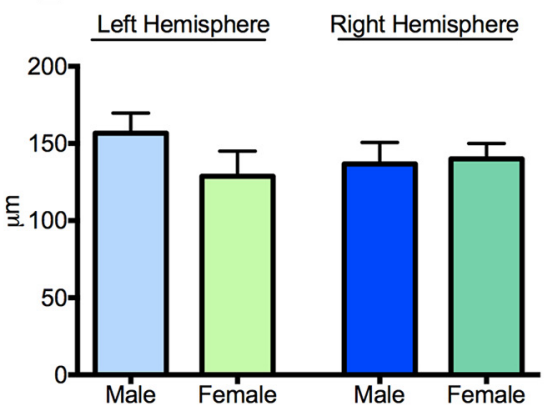

C

Number of Nodes

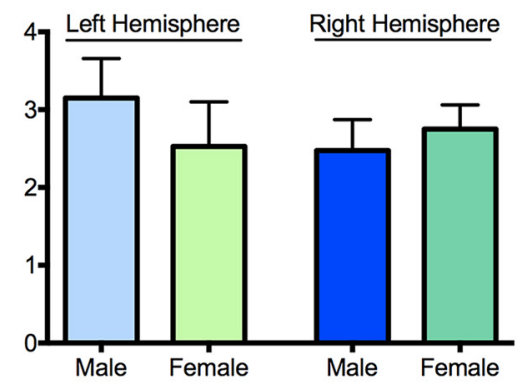

F

Average Dendrite Length

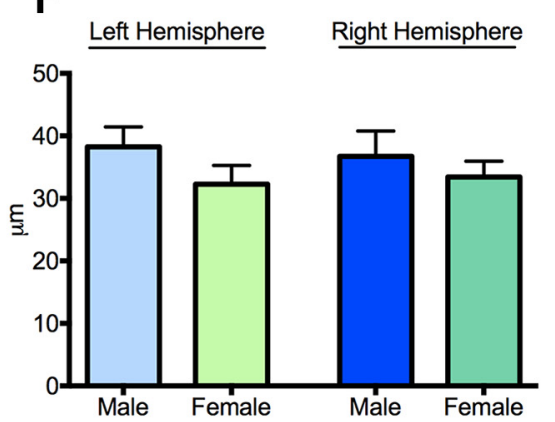

Fig. 8. Few sex differences are found in neurons in the neonatal medial amygdala. 3D reconstruction of PN4 Golgi-impregnated neurons in the medial amygdala revealed sex differences in the cell body area in both hemispheres $(\boldsymbol{A})$, but not in number of dendrites $(\boldsymbol{B})$, number of nodes $(\boldsymbol{C})$, spine density $(\boldsymbol{D})$, total dendritic length $(\boldsymbol{E})$, or average dendritic length $(\boldsymbol{F}) * p<0.05, n=10$ individuals per group, with six neurons per hemisphere reconstructed for each individual.

for sexual differentiation of the brain, resulting in higher levels of rough-and-tumble play in males. The neurobiological mechanisms by which this sex difference is established remain poorly understood. We here build on a previous observation of a role for the endocannabinoid system in masculinizing the neural circuits of play. We found that both CB1 and CB2 receptors are essential to masculinization of juvenile rough-and-tumble play behavior. Combined administration of CB1R and CB2R agonists to females during the sensitive period increased their play to the level of males, but the same treatment in males caused no further increase in play. Conversely, combined treatment with $\mathrm{CB} 1 \mathrm{R}$ and $\mathrm{CB} 2 \mathrm{R}$ antagonists decreased play in males to the level of females, without further decreasing play by females. The increase in female play behavior with CB1R and CB2R agonism and the decrease in male play behavior with CB1R and CB2R antagonism brought both pouncing and pinning components of play to the levels observed in the opposite sex, demonstrating full masculinization or feminization of the style of play following developmental manipulation of the endocan- nabinoid system. These data reveal cooperation between the CB1R and CB2R during development to direct development of the neural circuitry regulating juvenile play behavior.

For manipulations that resulted in feminization and masculinization of play, breakdown of play into the components of pouncing and pinning revealed some unexpected effects. In animals that had been treated neonatally with dual agonists, we observed an increase in female pouncing behavior, but saw a decrease in males. This opposite action between males and females could be the result of sex differences in the endocannabinoid system at the level of receptor expression or cell type localization of receptors. Additionally, our manipulations may have caused sex-specific compensatory mechanisms, such as desensitization of receptors or upregulation of endocannabinoids and their receptors. The existence of such compensatory mechanisms is supported by the observation that agonism did not produce a further increase in male play behavior and antagonism did not result in decreased female play behavior. It is unlikely that the lack 


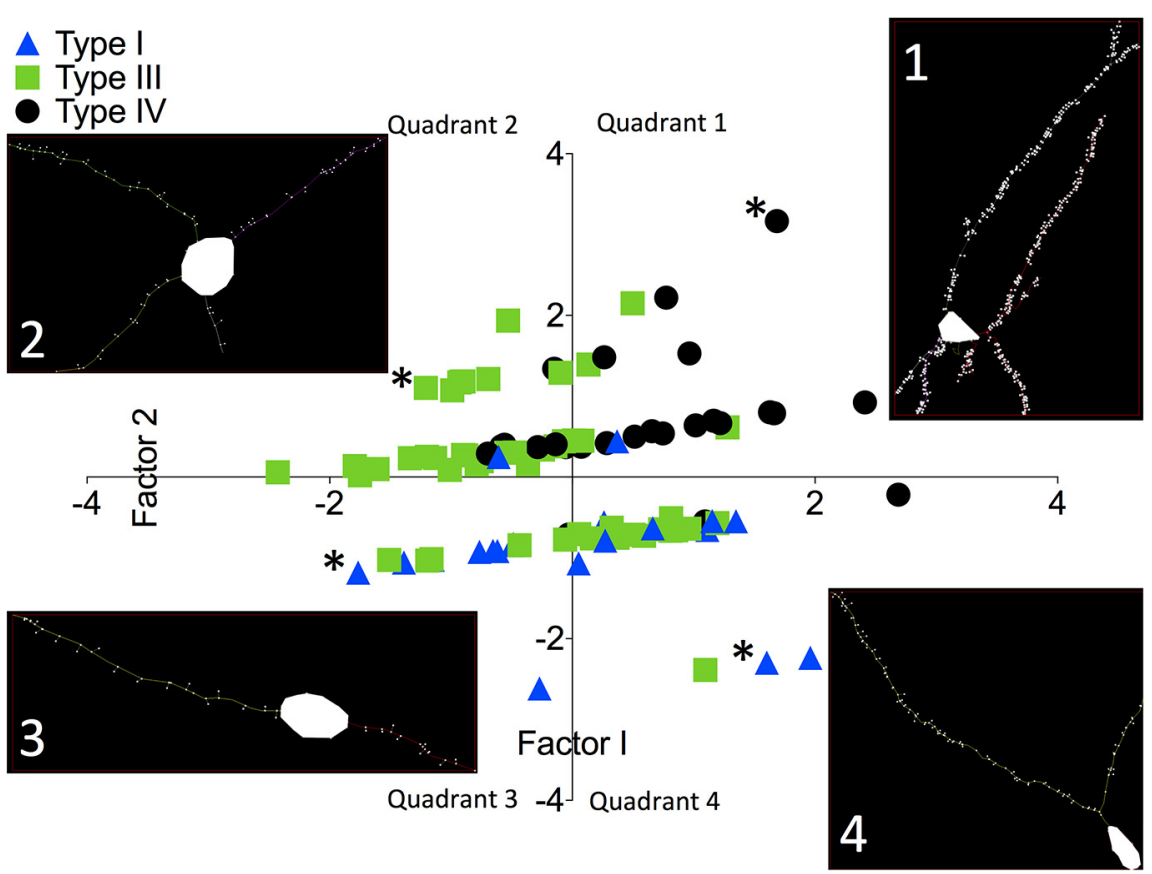

Fig. 9. Factor analysis separates neurons into groups based on observable differences in neuronal morphology. 3D reconstruction of male and female PN26 Golgi-impregnated neurons in the medial amygdala, separation of the neurons into classes based on cell body shape, spine frequency, or numbers of dendrites, and graphing by factor scores for Factor 1 (Dendritic Complexity) vs. Factor 2 (Dendritic Field) shows how classes of neurons cluster together within specific quadrants. Type I neurons (blue triangles) had spindle-shaped cell bodies, 1-3 primary dendrites and clustered within quadrants 3 and 4 . Type III neurons (green squares) contained ovoid cell body, 2-5 dendrites, moderate spine density, and clustered within quadrants 2 and 4 . Type IV neurons (black circles) had ovoid cell bodies, 3-5 primary dendrites, numerous spines, and clustered within quadrant 1 . In each quadrant, tracing for a representative neuron is shown with the corresponding data point indicated with an asterisk.

of effect in the opposite sex was due to ceiling or basement levels of play, since other manipulations, such as introduction of a novel play partner or social isolation, can decrease female play and increase male and female play, respectively (for example, Beatty et al., 1982; Argue and McCarthy, 2015a). Because dual antagonism of the receptors during development decreases pinning in juvenile males, it was surprising to find increased pinning with selective CB2R antagonism in males. Pinning requires action on the part of both animals involved in the play bout: the pinner needs to be standing on top of his/her opponent which usually occurs after a pounce, and the pinnee needs to rotate to a supine position. Because this increase in pinning occurred without a corresponding increase in pouncing, it is possible that it was the result of one or more of the other animals in the group rotating to supine without being first pounced on. Such rotation to supine in the absence of a pounce is a rare event; however, the likelihood of this occurring increases when there is an increase in the distance at which defense is initiated (Himmler et al., 2013, 2016). This suggests a difference in perception of the AM630-treated male as a potential play partner causing others to rotate as he approaches rather than waiting for the pounce. Further paired play studies will be needed to determine whether the difference in pinning was the result of interaction with a specific play partner. In two cases, neonatal treatment with WIN55,212-2 produced an effect different from that of ACEA+GP1a. WIN55,212-2 treatment induced an increased total fre- quency of play by females that was due mostly to an effect of pinning rather than a combination of pinning and pouncing as was observed with ACEA+GP1a treatment, and the same treatment produced a decrease in male pouncing that was not observed with WIN55,212-2. We expected WIN55,212-2 and ACEA+GP1a to have similar effects. A possible reason for these discrepancies is the CB2R binding bias of WIN55,212-2, rather than more equal distribution between CB1R and CB2R that is achieved with ACEA+GP1a. WIN55,212-2 has a $K_{i}$ of 62.3 $\mathrm{nM}$ at CB1R and $3.3 \mathrm{nM}$ at CB2R, whereas ACEA has a $K_{i}$ of $1.4 \mathrm{nM}$ for CB1R and GP1a has a $K_{i}$ of $0.037 \mathrm{~nm}$ for $\mathrm{CB} 2 \mathrm{R}$. There is also the possibility that once these agonists bind to their receptor, different downstream signaling pathways are activated, as seen by others (DelgadoPeraza et al., 2016; Dhopeshwarkar and Mackie, 2016).

Emphasis in research on the role of endocannabinoids in CNS development has been on CB1R, which is considered the most abundant G-protein-coupled receptor in the brain and is found at high to moderate levels throughout (Herkenham et al., 1990). In the adult brain CB1R is predominantly on presynaptic terminals of glutamatergic and GABA-ergic neurons, with lower expression on astrocytes and microglia (Herkenham et al., 1990; Galiègue et al., 1995; Elphick and Egertová, 2001; Stella, 2010). There is a developmental switch in CB1R distribution such that it begins in the white matter and then shifts to being more abundant in the gray matter as the brain matures (Berrendero et al., 1998). 


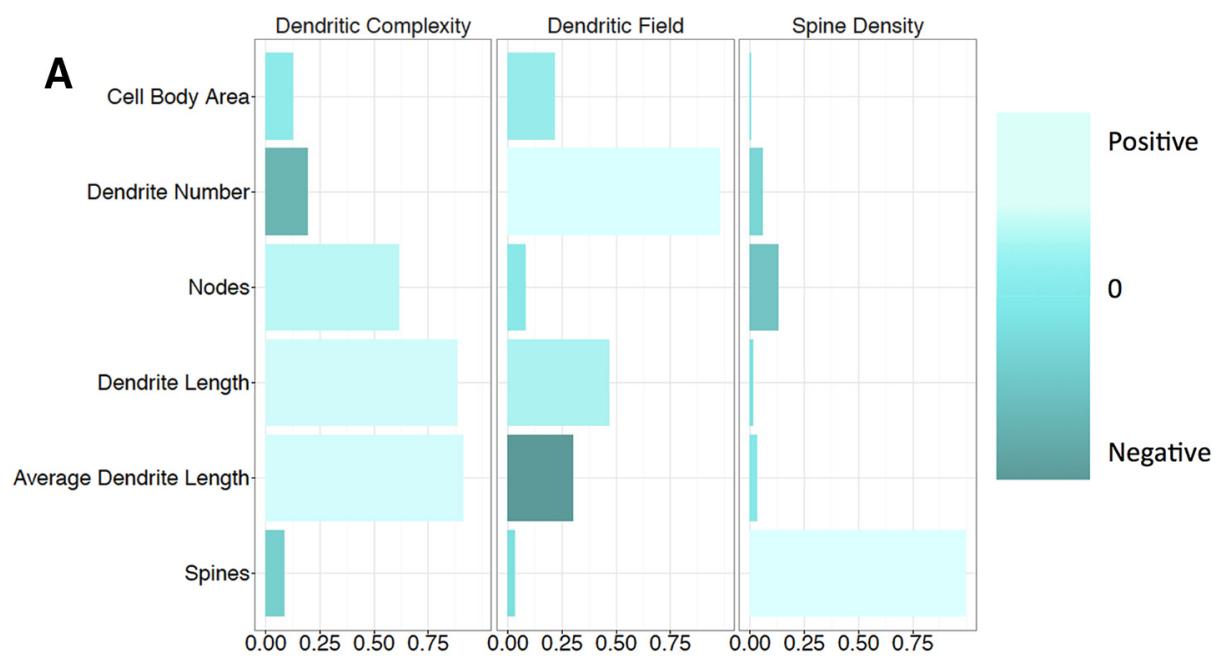

B Factor 1: Dendritic Complexity Left Hemisphere Right Hemisphere

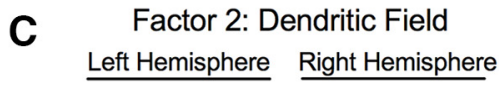

D Factor 3: Spine Density

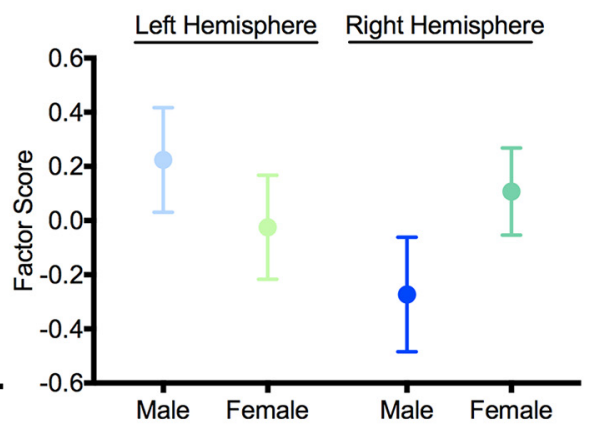

Fig. 10. Juvenile females have greater dendritic complexity in the right hemisphere relative to males. 3D reconstruction of male and female PN26 Golgi-impregnated neurons in the medial amygdala and factor analysis of cell body area, number of dendrites, number of nodes, total dendritic length, average dendritic length, and spine density $(\boldsymbol{A})$ identified three factors (Dendritic Complexity, Dendritic Field, and Spine Density) depicted with longer aqua (lighter) bars indicating positive loading of a parameter and teal (darker) indicating negative loading. Factor scores for neurons from vehicle males and females were plotted and compared for Dendritic Complexity (B), Dendritic Field $(\boldsymbol{C})$, and Spine Density $(\boldsymbol{D}) . * * p<0.01, n=3-5$ individuals per group, with six neurons per hemisphere reconstructed for each individual.

The role of CB2R in brain development is less explored and at times contradictory. Classically, CB2R is referred to as the peripheral endocannabinoid receptor (Munro et al., 1993). In recent years, however, there is growing evidence of the presence and abundance of CB2R in the CNS. Both CB1R and CB2R messenger RNAs can be detected in the brain of the developing fetus as early as 8 d of gestation in the laboratory rat (Buckley et al., 1998). Initial reports limited CB2R expression to microglia, the immune cells of the brain, or astrocytes, with expression on neurons still reserved only for CB1R (Núñez et al., 2004; Maresz et al., 2005; Benito et al., 2008; Racz et al., 2008a, 2008b). A few studies reported CB2R abundantly expressed on neurons throughout the brain, but full validation was lacking (Gong et al., 2006; Onaivi et al., 2006, 2008). In the ventral tegmental area of adult mice, CB2R receptors are immunohistochemically identified on dopaminergic neurons, where they modulate neuronal activity and dopamine-mediated cocaine self-administration, but these effects are absent in CB2R knockout mice (Zhang et al., 2014). CB2R is also localized to CA3 and CA2 pyramidal cells, where their activation leads to prolonged hyperpolarization (Stempel et al., 2016). Important to the current findings, all of these studies on CB2R localization were conducted in adults. Exceedingly little is known regarding the expression of this receptor in the developing brain.

The endocannabinoid system is critical for many neurodevelopmental processes, including neural progenitor proliferation and survival (Rueda et al., 2002; Aguado et al., 2005; Jiang et al., 2005; Palazuelos et al., 2006, 2012; Goncalves et al., 2008; Mulder et al., 2008; RubioAraiz et al., 2008; Galve-Roperh et al., 2013; Díaz-Alonso et al., 2015; Rivera et al., 2015), differentiation (Aguado et al., 2006; Gomez et al., 2010; Soltys et al., 2010; Galve-Roperh et al., 2013; Sun et al., 2013), and axonal growth and guidance (Williams et al., 2003; Berghuis et al., 2007; Mulder et al., 2008; Wu et al., 2010; Tortoriello et al., 2014). Potential endpoints for the modulation of social play behavior include cell proliferation or neuronal morphology in the medial amygdala. Krebs-Kraft et al. (2010) found a sex difference in cell proliferation that was 


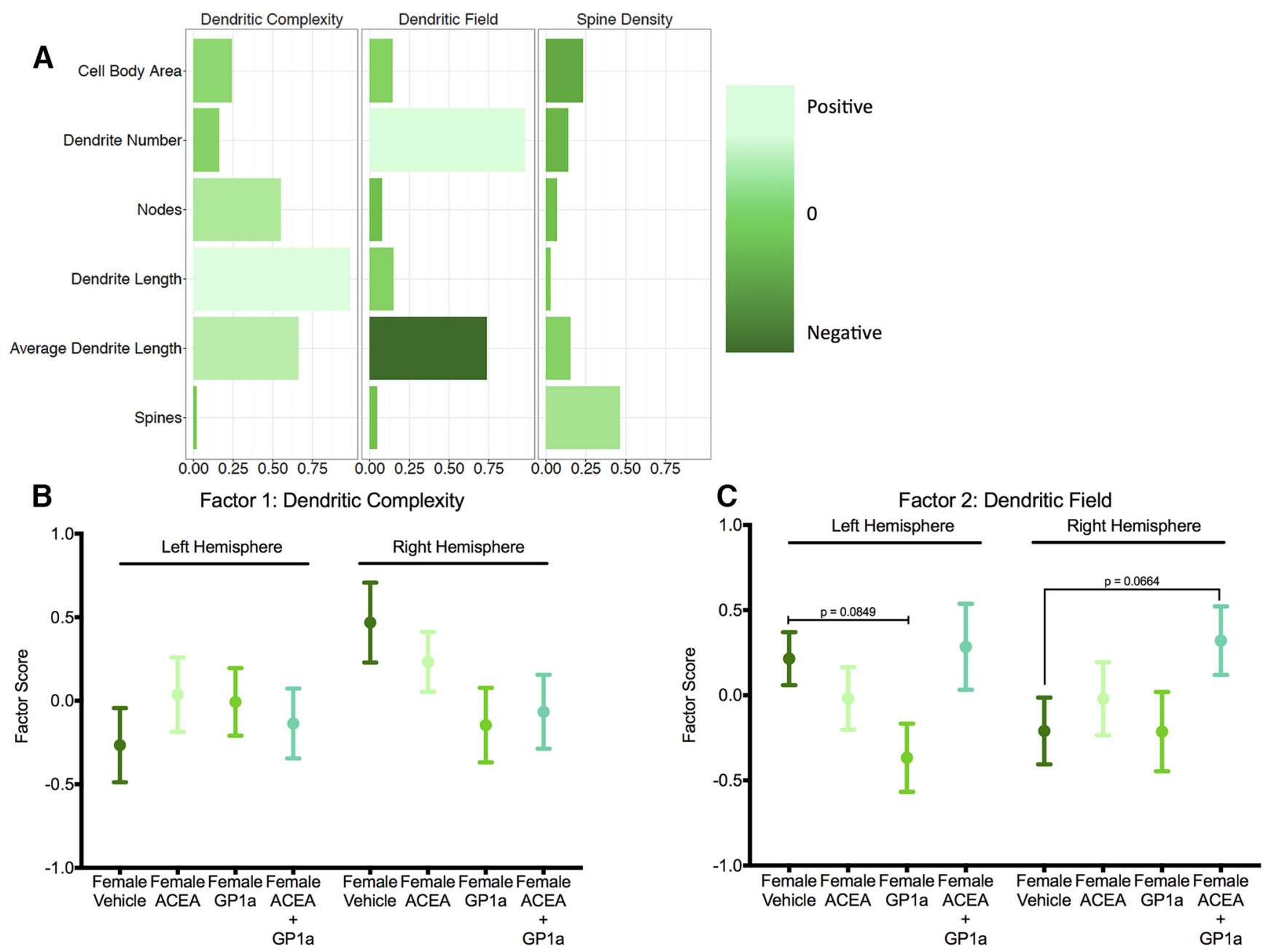

Fig. 11. Combined neonatal agonism of $C B 1 R$ and $C B 2 R$ uniquely shifted juvenile female dendritic field relative to selective agonism of either receptor. 3D reconstruction of female PN26 Golgi-impregnated neurons in the medial amygdala from animals treated neonatally with ACEA, GP1a, ACEA+GP1a, or vehicle and factor analysis of cell body area, number of dendrites, number of nodes, total dendritic length, average dendritic length, and spine density $(\boldsymbol{A})$ identified three factors (Dendritic Complexity, Dendritic Field, and Spine Density) depicted with longer light green bars indicating positive loading of a parameter and dark green indicating negative loading. Factor scores for neurons from ACEA, GP1a, ACEA+GP1a, and vehicle females were plotted and compared for Dendritic Complexity $(\boldsymbol{B})$ and Dendritic Field $(\boldsymbol{C})$. Exact $p$ values are indicated, $n=3-5$ individuals per group, with six neurons per hemisphere reconstructed for each individual.

due, in part, to higher numbers of newly proliferated astrocytes in the female neonatal medial amygdala, which is reversed by administration of WIN55,212-2 during the same period that WIN55,212-2 masculinizes female social play behavior. Combined treatment with WIN55,212-2 and antagonisms for CB1R or CB2R suggested, but did not confirm, that the effects were mediated by CB2R (Krebs-Kraft et al., 2010).

There is a sex difference in neuronal morphology in the medial amygdala of prepubertal rats, and sex differences in the number of neurons in the medial amygdala in adult animals is thought to be organized during early development (Cooke et al., 2007; Morris et al., 2008). These endpoints could work together, such that altering the number and type (i.e., neuron or astrocyte) during development could result in changed neuronal morphology. Additionally, there is a sex difference in the density of dendritic spines on neurons in the medial amygdala of adult rats, with males having greater spine frequency relative to females (Nishizuka et al., 1989). We did not find these same sex differences in the neonatal medial amygdala. It is possible that sex differences are present at this young age but are only noticeable once the neurons have extended further, or that our manipulations to the endocannabinoid system acted directly on a different aspect of neurodevelopment that produced later changes in neuronal morphology. In the juvenile medial amygdala, our factor analysis revealed sex differences in a factor comprised of measures of dendritic complexity (number of nodes, total dendritic length, and average dendritic length) in the right hemisphere. Neurons from females had higher factor scores for this factor, indicating that female neurons in the right hemisphere are more complex than males. We did not observe the previously reported sex differences, where males have greater dendritic branching and length in the left hemisphere and greater numbers of 

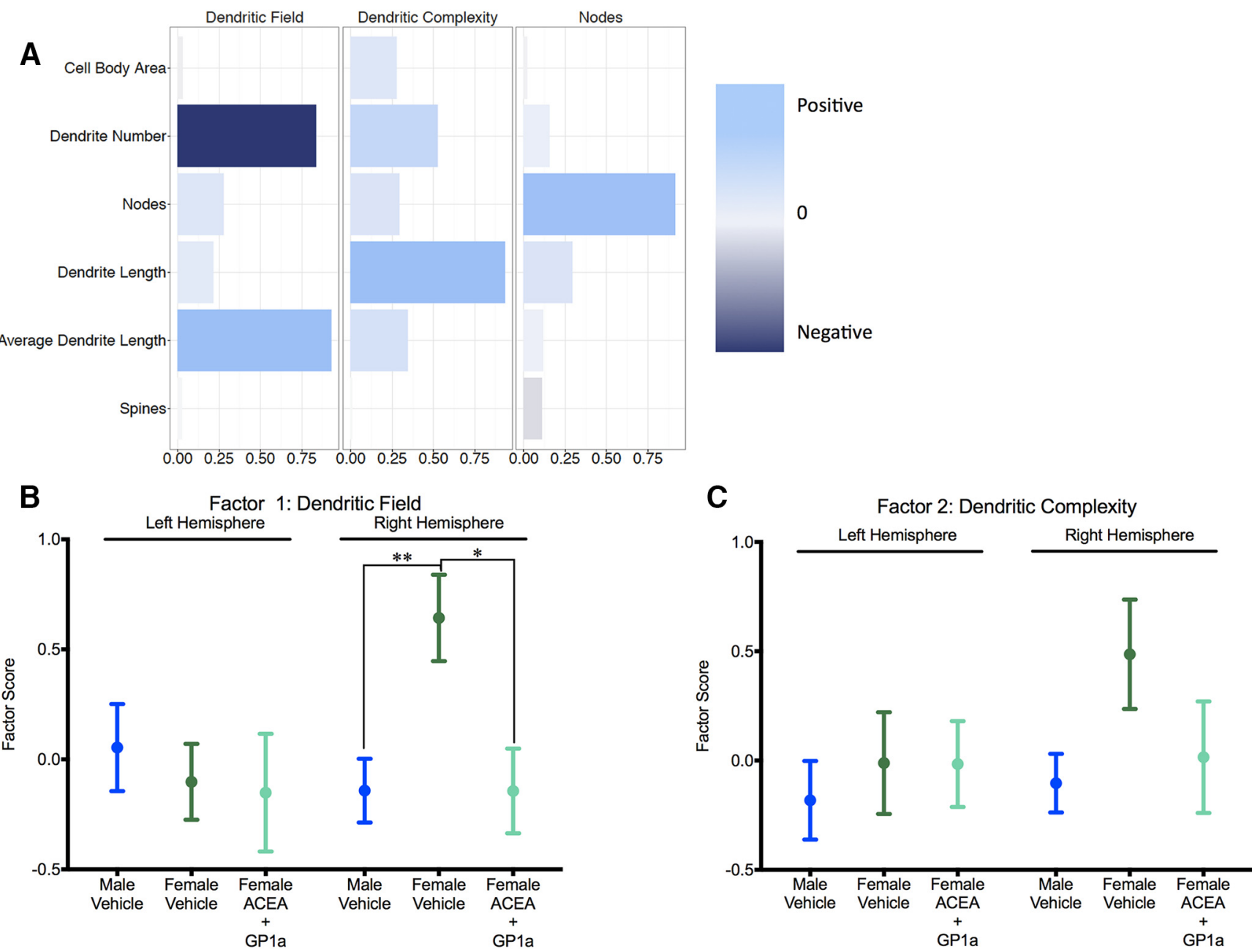

Fig. 12. Neonatal agonism of $C B 1 R$ and $C B 2 R$ masculinize juvenile female dendritic field in the right hemisphere. 3D reconstruction of male and female PN26 Golgi impregnated neurons in the medial amygdala from animals treated neonatally with ACEA+GP1a or vehicle and factor analysis of cell body area, number of dendrites, number of nodes, total dendritic length, average dendritic length, and spine density $(\boldsymbol{A})$ identified three factors (Dendritic Field, Dendritic Complexity, and Nodes) depicted with longer light blue bars indicating positive loading of a parameter and dark navy blue indicating negative loading. Factor scores for neurons from vehicle male and females and ACEA+GP1a-treated females were plotted and compared for Dendritic Field $(\boldsymbol{B})$ and Dendritic Complexity $(\boldsymbol{C})$. $* p$ $<0.05, * * p<0.01, n=3-5$ individuals per group, with 6 neurons per hemisphere reconstructed for each individual.

spines (Nishizuka et al., 1989; Cooke et al., 2007). Methodological differences between studies could account for some of the discrepancies, such as age of the animals, Golgi impregnation versus filling with biocytin, separation of the hemispheres, and classification of the neurons by general morphology. Our second factor analysis, designed to determine whether neonatal dual agonism of $\mathrm{CB} 1 \mathrm{R}$ and $\mathrm{CB} 2 \mathrm{R}$ affects neuronal morphology differently than select agonism of either receptor, demonstrated trends in the data that suggest a specific effect of simultaneous agonism that is not simply an addition of the effects observed when CB1R and CB2R are activated separately. Our third factor analysis determined that neonatal dual agonism of CB1R and CB2R was sufficient to masculinize dendritic field, which consisted of a negative association between the number of dendrites and the average dendritic length, in the right hemisphere. This analysis also suggested a slight trend toward masculinization of dendritic complexity (number of dendrites and total and averaged dendritic length) in the right hemisphere. Because our factor analysis of juvenile neuronal morphology was performed on a different cohort of animals from those that were used for the analysis of play behavior, a direct association between neuronal morphology and play behavior was not possible. However, there was a clear correlation between the requirement for activation of both CB1R and CB2R during the early neonatal period to masculinize juvenile female play behavior and the ability of this same treatment paradigm to shift neuronal morphology in the right hemisphere of the female medial amygdala closer to that of males.

In the current study, endocannabinoid receptor agonists and antagonists were given i.p.; therefore, we cannot rule out the potential of a peripheral mechanism of action. CB1R is lower in the periphery relative to the brain, and the opposite is true for CB2R (Galiègue et al., 1995). CB1R is mainly in the gastrointestinal tract, heart, liver, adipose tissue, lungs, adrenal glands, muscle, reproduc- 
tive system, bone, and skin, whereas CB2R is associated with immune-related organs and cells, such as monocytes, macrophages, B and T cells, mast cells, keratinocytes, spleen, tonsils, thymus gland, and gastrointestinal tract (Izzo, 2004; Ständer et al., 2005; Matias and Di Marzo, 2006, 2007; lannotti et al., 2014; Staiano et al., 2016). There is a precedent for communication between the peripheral immune system and the CNS. Under certain stress conditions, peripheral monocytes are recruited into the brain where they cause an increase in central inflammatory signaling (Weber et al., 2017). This process requires changes to blood-brain barrier permeability and a breakdown of astrocytic barriers (Weber et al., 2017). Manipulations to the endocannabinoid system could cause an increase in either pro- or anti-inflammatory signaling in peripheral immune components that then access the brain. Modulation of the endocannabinoid system may also directly induce changes to the blood-brain barrier (Engelhardt, 2003; Rom et al., 2013; Vendel and de Lange, 2014), thereby altering the inflammatory status of the brain, without acting on receptors located within the CNS. This peripheral mechanism of action is not necessarily mutually exclusive with a central mechanism of action. If we are to take the canonical classification of CB1R as central and CB2R as peripheral, then changes to CB2R signaling in the periphery may alter the peripheral immune system, which then communicates to the brain and alters CB1R signaling.

In summary, these data demonstrate sex-specific modulation of the developmental organization of juvenile rough-and-tumble play behavior via simultaneous signaling through both $\mathrm{CB} 1$ and $\mathrm{CB} 2$ receptors. Further investigation into how the endocannabinoid system interacts with sex steroid hormones and how CB1 and CB2 receptors act in cooperation to modulate acquisition of sexually differentiated play behavior will provide valuable insight into the functioning of the endocannabinoid system during early brain development and highlight potential ways in which cannabis use during pregnancy could have unintended effects on the developing fetus.

\section{References}

Aguado T, Monory K, Palazuelos J, Stella N, Cravatt B, Lutz B, Marsicano G, Kokaia Z, Guzmán M, Galve-Roperh I (2005) The endocannabinoid system drives neural progenitor proliferation. FASEB J 19:1704-1706.

Aguado T, Palazuelos J, Monory K, Stella N, Cravatt B, Lutz B, Marsicano G, Kokaia Z, Guzmán M, Galve-Roperh I (2006) The endocannabinoid system promotes astroglial differentiation by acting on neural progenitor cells. J Neurosci 26:1551-1561. CrossRef

Amateau SK, McCarthy MM (2004) Induction of PGE2 by estradiol mediates developmental masculinization of sex behavior. Nat Neurosci 7:643-650. CrossRef Medline

Argue KJ, McCarthy MM (2015a) Characterization of juvenile play in rats: importance of sex of self and sex of partner. Biol Sex Differ 6:16. CrossRef Medline

Argue KJ, McCarthy MM (2015b) Utilization of same- vs. mixed-sex dyads impacts the observation of sex differences in juvenile social play behavior. Curr Neurobiol 6:17-23. CrossRef Medline

Arthur M, Bochner S, Butterfield N (1999) Enhancing peer interactions within the context of play. Int J Disabil Dev Educ 46:367-381. CrossRef
Auger AP, Olesen KM (2009) Brain sex differences and the organisation of juvenile social play behaviour. J Neuroendocrinol 21: 519-525. CrossRef Medline

Barrett L, Dunbar RIM, Dunbar P (1992) Environmental influences on play behaviour in immature gelada baboons. Anim Behav 44:111115. CrossRef

Beatty WW, Dodge AM, Dodge LJ, White K, Panksepp J (1982) Psychomotor stimulants, social deprivation and play in juvenile rats. Pharmacol Biochem Behav 16:417-422. Medline

Benito C, Tolón RM, Pazos MR, Núñez E, Castillo Al, Romero J (2008) Cannabinoid CB2 receptors in human brain inflammation. Br J Pharmacol 153:277-285. CrossRef Medline

Berghuis P, Rajnicek AM, Morozov YM, Ross RA, Mulder J, Urbán GM, Monory K, Marsicano G, Matteoli M, Canty A, Irving AJ, Katona I, Yanagawa Y, Rakic P, Lutz B, Mackie K, Harkany T (2007) Hardwiring the brain: endocannabinoids shape neuronal connectivity. Science 316:1212-1216. CrossRef Medline

Berrendero F, García-Gil L, Hernández ML, Romero J, Cebeira M, de Miguel R, Ramos JA, Fernández-Ruiz JJ (1998) Localization of mRNA expression and activation of signal transduction mechanisms for cannabinoid receptor in rat brain during fetal development. Development 125:3179-3188.

Buckley NE, Hansson S, Harta G, Mezey E (1998) Expression of the $\mathrm{CB} 1$ and $\mathrm{CB} 2$ receptor messenger RNAs during embryonic development in the rat. Neuroscience 82:1131-1149. Medline

Byers JA, Walker C (1995) Refining the motor training hypothesis for the evolution of play. Am Nat 146:25. CrossRef

Cheney DL (1978) The play partners of immature baboons. Anim Behav 26:1038-1050. CrossRef

Cooke BM, Stokas MR, Woolley CS (2007) Morphological sex differences and laterality in the prepubertal medial amygdala. J Comp Neurol 501:904-915. CrossRef Medline

Cordier R, Bundy A, Hocking C, Einfeld S (2010) Empathy in the play of children with attention deficit hyperactivity disorder. OTJR Occup Particip Health 30:122-132. CrossRef

Cordoni G (2009) Social play in captive wolves (Canis lupus): not only an immature affair. Behaviour 146:1363-1385. CrossRef

Delgado-Peraza F, Ahn KH, Nogueras-Ortiz C, Mungrue IN, Mackie K, Kendall DA, Yudowski GA (2016) Mechanisms of biased $\beta$-arrestin-mediated signaling downstream from the cannabinoid 1 receptor. Mol Pharmacol 89:618-629. CrossRef Medline

Dhopeshwarkar A, Mackie K (2016) Functional selectivity of CB2 cannabinoid receptor ligands at a canonical and noncanonical pathway. J Pharmacol Exp Ther 358:342-351. CrossRef Medline

Díaz-Alonso J, Aguado T, de Salas-Quiroga A, Ortega Z, Guzmán M, Galve-Roperh I (2015) CB1 Cannabinoid receptor-dependent activation of mTORC1/Pax6 signaling drives Tbr2 expression and basal progenitor expansion in the developing mouse cortex. Cereb Cortex 25:2395-2408.

Elphick MR, Egertová M (2001) The neurobiology and evolution of cannabinoid signalling. Philos Trans R Soc Lond B Biol Sci 356: 381-408. CrossRef Medline

Engelhardt B (2003) Development of the blood-brain barrier. Cell Tissue Res 314:119-129. CrossRef Medline

Galiègue S, Mary S, Marchand J, Dussossoy D, Carrière D, Carayon P, Bouaboula M, Shire D, Le Fur G, Casellas P (1995) Expression of central and peripheral cannabinoid receptors in human immune tissues and leukocyte subpopulations. Eur J Biochem 232:54-61. CrossRef

Galve-Roperh I, Chiurchiù V, Díaz-Alonso J, Bari M, Guzmán M, Maccarrone M (2013) Cannabinoid receptor signaling in progenitor/stem cell proliferation and differentiation. Prog Lipid Res 52: 633-650. CrossRef Medline

Gomez O, Arevalo-Martin A, Garcia-Ovejero D, Ortega-Gutierrez S, Cisneros JA, Almazan G, Sánchez-Rodriguez MA, Molina-Holgado $F$, Molina-Holgado E (2010) The constitutive production of the endocannabinoid 2-arachidonoylglycerol participates in oligodendrocyte differentiation. Glia 58:1913-1927. CrossRef Medline

Goncalves MB, Suetterlin P, Yip P, Molina-Holgado F, Walker DJ, Oudin MJ, Zentar MP, Pollard S, Yáñez-Muñoz RJ, Williams G, 
Walsh FS, Pangalos MN, Doherty P (2008) A diacylglycerol lipaseCB2 cannabinoid pathway regulates adult subventricular zone neurogenesis in an age-dependent manner. Mol Cell Neurosci 38:526-536. CrossRef

Gong J-P, Onaivi ES, Ishiguro H, Liu Q-R, Tagliaferro PA, Brusco A, Uhl GR (2006) Cannabinoid CB2 receptors: immunohistochemical localization in rat brain. Brain Res 1071:10-23. CrossRef Medline

Graham KL, Burghardt GM (2010) Current perspectives on the biological study of play: signs of progress. Q Rev Biol 85:393-418. Medline

Gruendel AD, Arnold WJ (1969) Effects of early social deprivation on reproductive behavior of male rats. J Comp Physiol Psychol 67: 123-128. Medline

Henry JD, Herrero SM (1974) Social play in the American black bear: its similarity to canid social play and an examination of its identifying characteristics. Integr Comp Biol 14:371-389. CrossRef

Herkenham M, Lynn AB, Little MD, Johnson MR, Melvin LS, de Costa BR, Rice KC (1990) Cannabinoid receptor localization in brain. Proc Natl Acad Sci U S A 87:1932-1936. Medline

Himmler SM, Himmler BT, Stryjek R, Pellis SM (2016) Pinning in the play fighting of rats: A comparative perspective with methodological recommendations. Int J Comp Psychol 87.

Himmler SM, Modlinska K, Stryjek R, Himmler BT, Pisula W, Pellis SM (2014) Domestication and diversification: a comparative analysis of the play fighting of the Brown Norway, Sprague-Dawley, and Wistar laboratory strains of (Rattus norvegicus). J Comp Psychol 128:318-327. CrossRef

Himmler BT, Stryjek R, Modlinska K, Derksen SM, Pisula W, Pellis SM (2013) How domestication modulates play behavior: a comparative analysis between wild rats and a laboratory strain of Rattus norvegicus. J Comp Psychol 127:453-464. CrossRef

lannotti FA, Silvestri C, Mazzarella E, Martella A, Calvigioni D, Piscitelli F, Ambrosino P, Petrosino S, Czifra G, Bíró T, Harkany T, Taglialatela M, Di Marzo V (2014) The endocannabinoid 2-AG controls skeletal muscle cell differentiation via CB1 receptordependent inhibition of Kv7 channels. Proc Natl Acad Sci U S A 111:E2472-E2481. CrossRef Medline

Izzo AA (2004) Cannabinoids and intestinal motility: welcome to CB2 receptors. Br J Pharmacol 142:1201-1202. CrossRef Medline

Jiang W, Zhang Y, Xiao L, Van Cleemput J, Ji S-P, Bai G, Zhang $\times$ (2005) Cannabinoids promote embryonic and adult hippocampus neurogenesis and produce anxiolytic- and antidepressant-like effects. J Clin Invest 115:3104-3116. CrossRef Medline

Jordan R (2003) Social play and autistic spectrum disorders: a perspective on theory, implications and educational approaches. Autism Int J Res Pract 7:347-360. CrossRef Medline

Krebs-Kraft DL, Hill MN, Hillard CJ, McCarthy MM (2010) Sex difference in cell proliferation in developing rat amygdala mediated by endocannabinoids has implications for social behavior. Proc Natl Acad Sci U S A 107:20535-20540. CrossRef Medline

Leresche LA (1976) Dyadic play in Hamadryas baboons. Behaviour 57:190-205. CrossRef

Lu H-C, Mackie K (2015) An introduction to the endogenous cannabinoid system. Biol Psychiatr 79:516-525.

Maresz K, Carrier EJ, Ponomarev ED, Hillard CJ, Dittel BN (2005) Modulation of the cannabinoid CB2 receptor in microglial cells in response to inflammatory stimuli. J Neurochem 95:437-445. CrossRef Medline

Matias I, Di Marzo V (2006) Endocannabinoid synthesis and degradation, and their regulation in the framework of energy balance. $J$ Endocrinol Invest 29:15-26. Medline

Matias I, Di Marzo V (2007) Endocannabinoids and the control of energy balance. Trends Endocrinol Metab TEM 18:27-37. CrossRef Medline

Meaney MJ, McEwen BS (1986) Testosterone implants into the amygdala during the neonatal period masculinize the social play of juvenile female rats. Brain Res 398:324-328. Medline

Møller P, Husby R (2000) The initial prodrome in schizophrenia: searching for naturalistic core dimensions of experience and behavior. Schizophr Bull 26:217-232. Medline
Mong JA, Glaser E, McCarthy MM (1999) Gonadal steroids promote glial differentiation and alter neuronal morphology in the developing hypothalamus in a regionally specific manner. $J$ Neurosci 19:1464-1472.

Morris JA, Jordan CL, Breedlove SM (2008) Sexual dimorphism in neuronal number of the posterodorsal medial amygdala is independent of circulating androgens and regional volume in adult rats. J Comp Neurol 506:851-859. CrossRef Medline

Mulder J, Aguado T, Keimpema E, Barabás K, Ballester Rosado CJ, Nguyen L, Monory K, Marsicano G, Di Marzo V, Hurd YL, Guillemot F, Mackie K, Lutz B, Guzmán M, Lu H-C, Galve-Roperh I, Harkany T (2008) Endocannabinoid signaling controls pyramidal cell specification and long-range axon patterning. Proc Natl Acad Sci U S A 105:8760-8765. CrossRef Medline

Munro S, Thomas KL, Abu-Shaar M (1993) Molecular characterization of a peripheral receptor for cannabinoids. Nature 365:61-65. CrossRef Medline

Nishizuka M, Murakami S, Arai Y (1989) Neuronal structure and male-female difference in the medial amygdala of rats. Biomed Res 10:323-327.

Núñez E, Benito C, Pazos MR, Barbachano A, Fajardo O, González S, Tolón RM, Romero J (2004) Cannabinoid CB2 receptors are expressed by perivascular microglial cells in the human brain: an immunohistochemical study. Synap 53:208-213. CrossRef

Olioff M, Stewart J (1978) Sex differences in the play behavior of prepubescent rats. Physiol Behav 20:113-115. Medline

Onaivi ES et al. (2008) Brain neuronal CB2 cannabinoid receptors in drug abuse and depression: from mice to human subjects. PloS One 3:e1640. CrossRef Medline

Onaivi ES, Ishiguro H, Gong J-P, Patel S, Perchuk A, Meozzi PA, Myers L, Mora Z, Tagliaferro P, Gardner E, Brusco A, Akinshola BE, Liu Q-R, Hope B, Iwasaki S, Arinami T, Teasenfitz L, Uhl GR (2006) Discovery of the presence and functional expression of cannabinoid CB2 receptors in brain. Ann N Y Acad Sci 1074:514536. CrossRef

Palagi E, Antonacci D, Cordoni G (2007) Fine-tuning of social play in juvenile lowland gorillas (Gorilla gorilla gorilla). Dev Psychobiol 49:433-445. CrossRef Medline

Palazuelos J, Aguado T, Egia A, Mechoulam R, Guzmán M, GalveRoperh I (2006) Non-psychoactive CB2 cannabinoid agonists stimulate neural progenitor proliferation. FASEB J 20:2405-2407. CrossRef Medline

Palazuelos J, Ortega Z, Díaz-Alonso J, Guzmán M, Galve-Roperh I (2012) CB2 cannabinoid receptors promote neural progenitor cell proliferation via mTORC1 signaling. J Biol Chem 287:1198-1209. CrossRef Medline

Parent $\mathrm{Cl}$, Meaney MJ (2008) The influence of natural variations in maternal care on play fighting in the rat. Dev Psychobiol 50:767776. CrossRef Medline

Pellis SM (2002) Sex differences in play fighting revisited: traditional and nontraditional mechanisms of sexual differentiation in rats. Arch Sex Behav 31:17-26. Medline

Pellis SM, Field EF, Smith LK, Pellis VC (1997) Multiple differences in the play fighting of male and female rats. Implications for the causes and functions of play. Neurosci Biobehav Rev 21:105-120. Medline

Pellis SM, Pellis VC (1997) The prejuvenile onset of play fighting in laboratory rats (Rattus norvegicus). Dev Psychobiol 31:193-205. Medline

Pellis SM, Pellis VC (1998) Play fighting of rats in comparative perspective: a schema for neurobehavioral analyses. Neurosci Biobehav Rev 23:87-101. Medline

Pellis SM, Pellis VC, Bell HC (2010) The function of play in the development of the social brain. Am J Play 279-296.

Racz I, Nadal X, Alferink J, Baños JE, Rehnelt J, Martín M, Pintado B, Gutierrez-Adan A, Sanguino E, Bellora N, Manzanares J, Zimmer A, Maldonado R (2008a) Interferon-gamma is a critical modulator of $\mathrm{CB}(2)$ cannabinoid receptor signaling during neuropathic pain. $J$ Neurosci 28:12136-12145. 
Racz I, Nadal X, Alferink J, Baños JE, Rehnelt J, Martín M, Pintado B, Gutierrez-Adan A, Sanguino E, Manzanares J, Zimmer A, Maldonado $\mathrm{R}$ (2008b) Crucial role of $\mathrm{CB}(2)$ cannabinoid receptor in the regulation of central immune responses during neuropathic pain. $J$ Neurosci 28:12125-12135.

Rivera P, Bindila L, Pastor A, Pérez-Martín M, Pavón FJ, Serrano A, de la Torre R, Lutz B, Rodríguez de Fonseca F, Suárez J (2015) Pharmacological blockade of the fatty acid amide hydrolase (FAAH) alters neural proliferation, apoptosis and gliosis in the rat hippocampus, hypothalamus and striatum in a negative energy context. Front Cell Neurosci 9:98. CrossRef

Rom S, Zuluaga-Ramirez V, Dykstra H, Reichenbach NL, Pacher P, Persidsky Y (2013) Selective activation of cannabinoid receptor 2 in leukocytes suppresses their engagement of the brain endothelium and protects the blood-brain barrier. Am J Pathol 183:15481558. CrossRef Medline

Rubio-Araiz A, Arévalo-Martín A, Gómez-Torres O, Navarro-Galve B, García-Ovejero D, Suetterlin P, Sánchez-Heras E, Molina-Holgado E, Molina-Holgado F (2008) The endocannabinoid system modulates a transient TNF pathway that induces neural stem cell proliferation. Mol Cell Neurosci 38:374-380. CrossRef Medline

Rueda D, Navarro B, Martinez-Serrano A, Guzman M, Galve-Roperh I (2002) The endocannabinoid anandamide inhibits neuronal progenitor cell differentiation through attenuation of the Rap1/B-Raf/ ERK pathway. J Biol Chem 277:46645-46650. CrossRef Medline

Siviy SM (2016) A brain motivated to play: insights into the neurobiology of playfulness. Behaviour 153:819-844. CrossRef

Soltys J, Yushak M, Mao-Draayer Y (2010) Regulation of neural progenitor cell fate by anandamide. Biochem Biophys Res Commun 400:21-26. CrossRef Medline

Spinka M, Newberry RC, Bekoff M (2001) Mammalian play: training for the unexpected. Q Rev Biol 76:141-168. Medline

Staiano RI, Loffredo S, Borriello F, lannotti FA, Piscitelli F, Orlando P, Secondo A, Granata F, Lepore MT, Fiorelli A, Varricchi G, Santini M, Triggiani M, Di Marzo V, Marone G (2016) Human lung-resident macrophages express $\mathrm{CB} 1$ and $\mathrm{CB} 2$ receptors whose activation inhibits the release of angiogenic and lymphangiogenic factors. $J$ Leukoc Biol 99:531-540. CrossRef Medline

Ständer S, Schmelz M, Metze D, Luger T, Rukwied R (2005) Distribution of cannabinoid receptor 1 (CB1) and 2 (CB2) on sensory nerve fibers and adnexal structures in human skin. J Dermatol Sci 38:177-188. CrossRef Medline

Stella N (2010) Cannabinoid and cannabinoid-like receptors in microglia, astrocytes, and astrocytomas. Glia 58:1017-1030. CrossRef Medline

Stempel AV, Stumpf A, Zhang H-Y, Özdoğan T, Pannasch $U$, Theis A-K, Otte D-M, Wojtalla A, Rácz I, Ponomarenko A, Xi Z-X, Zimmer A, Schmitz D (2016) Cannabinoid type 2 receptors mediate a cell type-specific plasticity in the hippocampus. Neuron 90:795-809. CrossRef Medline
Strous RD, Alvir JMJ, Robinson D, Gal G, Sheitman B, Chakos M, Lieberman JA (2004) Premorbid functioning in schizophrenia: relation to baseline symptoms, treatment response, and medication side effects. Schizophr Bull 30:265-278. CrossRef

Sun J, Fang Y, Chen T, Guo J, Yan J, Song S, Zhang L, Liao H (2013) WIN55, 212-2 promotes differentiation of oligodendrocyte precursor cells and improve remyelination through regulation of the phosphorylation level of the ERK 1/2 via cannabinoid receptor 1 after stroke-induced demyelination. Brain Res 1491:225-235. CrossRef

Takahashi LK, Lore RK (1983) Play fighting and the development of agonistic behavior in male and female rats. Aggress Behav 9:217227. CrossRef

Thor DH, Holloway WR (1985) Play soliciting behavior in prepubertal and postpubertal male rats. Anim Learn Behav 13:327-330. CrossRef

Thor DH, Holloway WR (1986) Social play soliciting by male and female juvenile rats: effects of neonatal androgenization and sex of cagemates. Behav Neurosci 100:275-279. Medline

Tortoriello G, Morris CV, Alpar A, Fuzik J, Shirran SL, Calvigioni D, Keimpema E, Botting $\mathrm{CH}$, Reinecke K, Herdegen T, Courtney M, Hurd YL, Harkany $T$ (2014) Miswiring the brain: $\Delta 9$ tetrahydrocannabinol disrupts cortical development by inducing an SCG10/stathmin-2 degradation pathway. EMBO J 33:668-685. CrossRef Medline

van den Berg CL, Hol T, Van Ree JM, Spruijt BM, Everts H, Koolhaas JM (1999) Play is indispensable for an adequate development of coping with social challenges in the rat. Dev Psychobiol 34:129138. Medline

Vendel E, de Lange ECM (2014) Functions of the CB1 and CB 2 receptors in neuroprotection at the level of the blood-brain barrier. Neuromol Med 16:620-642. CrossRef Medline

Watson DM, Croft DB (1993) Playfighting in captive red-necked wallabies, Macropus rufogriseus banksianus. Behaviour 126:219245. CrossRef

Weber MD, Godbout JP, Sheridan JF (2017) Repeated social defeat, neuroinflammation, and behavior: monocytes carry the signal. Neuropsychopharmacology 42:46-61.

Williams E-J, Walsh FS, Doherty P (2003) The FGF receptor uses the endocannabinoid signaling system to couple to an axonal growth response. J Cell Biol 160:481-486. CrossRef Medline

Wu C-S, Zhu J, Wager-Miller J, Wang S, O'Leary D, Monory K, Lutz $B$, Mackie K, Lu H-C (2010) Requirement of cannabinoid CB(1) receptors in cortical pyramidal neurons for appropriate development of corticothalamic and thalamocortical projections. Eur $\mathrm{J}$ Neurosci 32:693-706. CrossRef Medline

Zhang H-Y, Gao M, Liu Q-R, Bi G-H, Li X, Yang H-J, Gardner EL, Wu J, Xi Z-X (2014) Cannabinoid CB2 receptors modulate midbrain dopamine neuronal activity and dopamine-related behavior in mice. Proc Natl Acad Sci U S A 111:E5007-E5015. CrossRef Medline 